\title{
Imipenem and meropenem: Comparison of in vitro activity, pharmacokinetics, clinical trials and adverse effects
}

\author{
George G Zhanel PharmD PhD ${ }^{1}$, Andrew E Simor MD ${ }^{3}$, Lavern Vercaigne PharmD ${ }^{2}$, Lionell Mandell MD ${ }^{4}$, \\ and the Canadian Carbapenem Discussion Group
}

\begin{abstract}
GG Zhanel, AE Simor, L Vercaigne, L Mandell and the Canadian Carbapenem Discussion Group. Imipenem and meropenem: Comparison of in vitro activity, pharmacokinetics, clinical trials and adverse effects. Can J Infect Dis $1998 ; 9(4): 215-228$.
\end{abstract}

OBJECTIVE: To compare and contrast imipenem and meropenem in terms of in vitro activity, pharmacokinetics, clinical efficacy and adverse effects.

DATA SELECTION: MEDLINE search from 1975 to 1997 and follow-up of references.

DATA EXTRACTION: Clinical trials comparing imipenem with meropenem, or either imipenem or meropenem with standard therapy in the treatment of serious infections were selected.

DATA SYNTHESIS: Imipenem, the first carbapenem, was first marketed in 1987; meropenem was introduced to the market in 1996. In general, imipenem is more active against Gram-positive cocci while meropenem is more active against Gram-negative bacilli. The agents display similar pharmacokinetics. Clinical studies in patients with serious infections (intra-abdominal infection, respiratory infection, septicemia, febrile neutropenia) report similar bacteriological and clinical cure rates with imipenem and meropenem. Meropenem is approved for the treatment of bacterial meningitis, whereas imipenem is not. Adverse effects are similar.

CONCLUSIONS: Current literature supports the use of imipenem at a dose of $500 \mathrm{mg}$ every $6 \mathrm{~h}$ and meropenem at $1 \mathrm{~g}$ every $8 \mathrm{~h}$ for the treatment of severe infections. For the treatment of serious infections, imipenem $(500 \mathrm{mg}$ every $6 \mathrm{~h}$ or $2 \mathrm{~g} /$ day [\$98/day]) is more economical than meropenem (1 $\mathrm{g}$ every $8 \mathrm{~h}$ or $3 \mathrm{~g} /$ day [ $\$ 142 /$ day]) based on acquisition cost.

Key Words: Imipenem, Meropenem

L'imipénem et le méropénem : comparaison de l'activité in vitro, de la pharmacocinétique, des essais cliniques et des réactions indésirables

OBJECTIF : Comparer et mettre en opposition l'imipénem et le méropénem en termes d'activité in vitro, de pharmacocinétique, d'efficacité clinique et de réactions indésirables.

SÉLECTION DES DONNÉES : Interrogation du réseau MEDLINE sur les publications parues entre 1975 et 1997 et consultation des sources bibliographiques.

EXTRACTION DES DONNÉES : Les essais cliniques comparant l'imipénem et le méropénem ou, l'imipénem ou le méropénem à un traitement classique dans les infections graves ont été sélectionnés.

voir page suivante

\footnotetext{
${ }^{1}$ Departments of Medicine and Microbiology, Health Sciences Centre and Faculties of Pharmacy and Medicine, University of Manitoba; ${ }^{2}$ Department of Pharmacy, University of Manitoba, Winnipeg, Manitoba; ${ }^{3}$ Department of Microbiology, Sunnybrook Health Sciences Centre, Toronto, Ontario; ${ }^{4}$ Department of Infectious Diseases, McMaster University, Hamilton, Ontario

Correspondence: Dr GG Zhanel, Health Sciences Centre, MS673 - 820 Sherbrook Street, Winnipeg, Manitoba R3A 1R9. Telephone 204-787-4902, fax 204-787-4699, e-mail ggzhanel@pcs.mb.ca

Received for publication June 11, 1997. Accepted November 11, 1997
} 
SYNTHÈSE DES DONNÉES : L'imipénem, premier carbapénem, a été mis en marché en 1987; le méropénem a été lancé sur le marché en 1996. En général, l’imipénem est plus efficace contre les cocci gram-positifs, alors que le méropénem est plus efficace contre les bacilles gram-négatifs. Les agents ont une pharmacocinétique similaire. Des études cliniques sur des patients atteints d'infections graves (infections intra-abdominales, infections respiratoires, septicémie, neutropénie fébrile) signalent des taux bactériologiques et des taux de guérison clinique similaires avec l'imipénem et le méropénem. Le méropénem est approuvé pour le traitement de la méningite bactérienne, contrairement à l'imipénem. Les réactions indésirables sont semblables.

CONCLUSIONS : La littérature actuelle appuie l'emploi de l'imipénem à raison de $500 \mathrm{mg}$ toutes les six heures et du méropénem à raison de $1 \mathrm{~g}$ toutes les huit heures pour le traitement de l'infection grave. Pour le traitement des infections graves, l'imipénem (500 mg toutes les six heures ou $2 \mathrm{~g} /$ jour [98 \$/jour]) est plus économique que le méropénem (1 $\mathrm{g}$ toutes les huit heures ou $3 \mathrm{~g} /$ jour [142 \$/jour]) sur la base du coût d'achat.

$\mathrm{I}_{\mathrm{b}}^{\mathrm{m}}$ mipenem was the first of a new class of antibiotics, the carbapenems (1). The parent substance, thienamycin, was isolated from the soil organism Streptomyces cattleya (2). However, because thienamycin spontaneously breaks down at high concentrations, the more stable amidine derivative $\mathrm{N}$ formimidoyl thienamycin, known as imipenem, was developed (Figure 1). Imipenem is administered in combination with an equal amount of cilastatin (Primaxin, Merck Sharp $\&$ Dohme), a compound that was specifically developed to inhibit metabolism of imipenem by the kidney. Imipenem, first marketed in Canada in 1987, immediately attracted attention because it possessed the most broad antibacterial spectrum of any antibiotic available at that time $(3,4)$. Imipenem is indicated for the treatment of a variety of serious infections, but not for meningitis.

Meropenem (Merrem, Zeneca), first marketed in Canada in 1996, was the second semisynthetic parenteral carbapenem available in Canada. Meropenem differs structurally from imipenem, primarily by the addition of a methyl group in the 1position of the carbapenem moiety (5) (Figure 1). This results in greater stability in vivo to inactivation by human renal dehydropeptidase-1 (DHP-1) than imipenem, with the result that meropenem need not be co-administered with cilastatin $(6,7)$. Meropenem is indicated for the treatment of a variety of serious infections and meningitis.

The purpose of this paper is to compare and contrast the in vitro activity, pharmacokinetics, clinical uses and adverse ef-

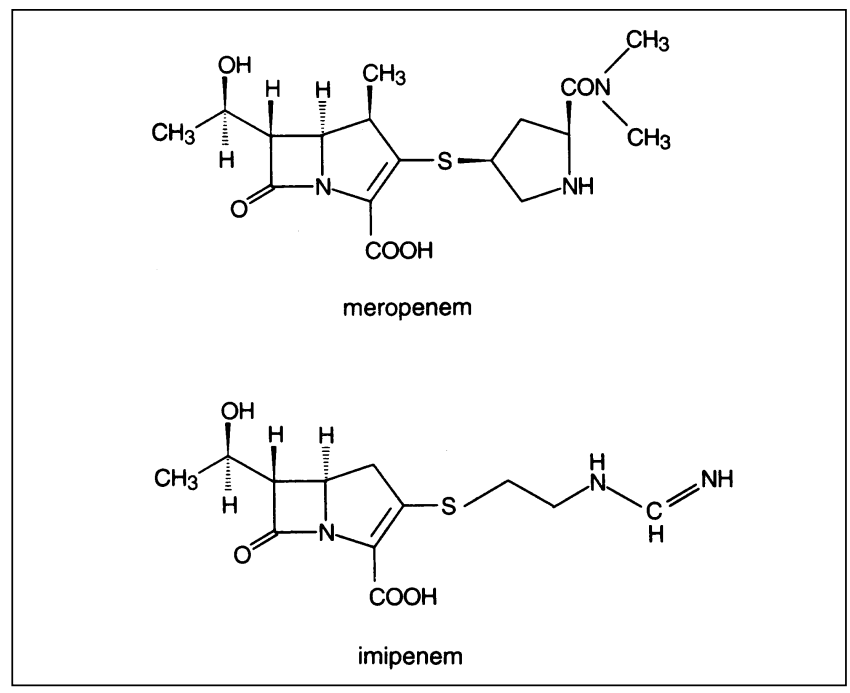

Figure 1) Chemical structures of meropenem and imipenem fects of imipenem and meropenem. The focus of this paper is the comparison of imipenem and meropenem in the treatment of serious infections (intra-abdominal infections, respiratory tract infections, septicemia, bacterial meningitis and febrile neutropenia). For simplicity, imipenem and imipenem/cilastatin are used interchangeably.

\section{MECHANISM OF ACTION}

Meropenem and imipenem are bactericidal against susceptible organisms as demonstrated by time-kill curve studies with Enterobacteriaceae (8-10). Both agents cause bacterial lysis in susceptible organisms by binding with high affinity to high molecular weight penicillin-binding proteins (PBPs). It is generally agreed that PBP 2 is the primary target of both meropenem and imipenem in Escherichia coli $(2,11,12)$. Additionally, with Gram-negative bacilli such as $E$ coli and Pseudomonas aeruginosa, meropenem demonstrates a high affinity for PBP 3 not found with imipenem, which may account for its enhanced activity against Gram-negative bacilli compared with imipenem (11). The relative PBP affinities of meropenem and imipenem in strains of Staphylococcus aureus are quite similar, each demonstrating high affinity for PBP 2, PBP 1 and PBP $4(12,13)$.

Both meropenem and imipenem are highly resistant to hydrolysis by most clinically important beta-lactamases, plasmid- or chromosomally mediated, of $S$ aureus, $E$ coli, Enterobacter species, Citrobacter freundii, Proteus species, Serratia marcescens, Klebsiella species, $P$ aeruginosa and Bacteroides fragilis (2,3,8,14-17).

In addition, meropenem and imipenem are unaffected by strains of Enterobacteriaceae that produce plasmid-mediated beta-lactamases derived from TEM and SHV enzymes which are capable of hydrolyzing third-generation cephalosporins, ie, extended spectrum beta-lactamases $(8,18,19)$. Both meropenem and imipenem are readily hydrolyzed by carbapenemhydrolyzing beta-lactamases produced by Stenotrophomonas maltophilia and occasionally in strains of Bacteroides species, Bacillus cereus and Aeromonas hydrophila $(1,7,20,21)$.

Unlike most beta-lactams (penicillins, cephalosporins, monobactams), carbapenems demonstrate a long, dosedependent postantibiotic effect (PAE) against Gram-negative organisms $(22,23)$. This effect makes carbapenems more similar to fluoroquinolones and aminoglycosides than betalactams. PAEs for meropenem and imipenem range from 2 to $9 \mathrm{~h}$ depending on the organism and concentration of antimicrobial studied (22-24). In addition, limited data suggest that 
TABLE 1

Antibacterial activity (minimum inhibitory concentration of $90 \%$ of isolates $\mu \mathrm{g} / \mathrm{mL}$ ) of imipenem and meropenem in comparison with ceftazidime, piperacillin/tazobactam, gentamicin and ciprofloxacin against Gram-positive aerobes

\begin{tabular}{|c|c|c|c|c|c|c|}
\hline Gram-positive aerobes & Imipenem & Meropenem & Ceftazidime & Piperacillin/tazobactam & Gentamicin & Ciprofloxacin \\
\hline Staphylococcus aureus (MS) & 0.06 & 0.25 & $>16$ & 1 & 16 & 0.5 \\
\hline$S$ aureus (MR) & 8 & 16 & 64 & 128 & 16 & 2 \\
\hline S epidermidis (MR) & 16 & 16 & 64 & 128 & 16 & 16 \\
\hline Staphylococcus saprophyticus & 0.03 & 0.25 & 32 & 0.25 & 0.06 & 8 \\
\hline Streptococcus pyogenes & $<0.06$ & $<0.06$ & 0.12 & 0.25 & 16 & 1 \\
\hline Streptococcus pneumoniae (PS) & 0.03 & 0.06 & 0.25 & 0.06 & 16 & 2 \\
\hline S pneumoniae (PR) & 0.25 & 1 & 32 & 2 & 16 & 2 \\
\hline Enterococcus faecalis & 2 & 8 & $>128$ & 4 & 128 & 4 \\
\hline Enterococcus faecium & 32 & 64 & $>128$ & 128 & 128 & 16 \\
\hline Listeria monocytogenes & 0.25 & 0.25 & 128 & 2 & 4 & 1 \\
\hline
\end{tabular}

Adapted from references 1,3-8,10,11,16,17,30-40. In vitro susceptibility of imipenem and meropenem: susceptible $4 \mu \mathrm{g} / \mathrm{mL}$ or less, intermediate $8 \mu \mathrm{g} / \mathrm{mL}$, resistant $16 \mu \mathrm{g} / \mathrm{mL}$ or more. MR Methicillin-resistant; MS Methicillin-susceptible; PR Penicillin-resistant; PS Penicillin-susceptible

carbapenems, unlike penicillin and cephalosporins, may demonstrate an element of dose-dependent bacterial killing (2224). These data suggest that optimal dosing of these agents may be obtained if they are administered less frequently (longer dosing interval) but at higher doses. Higher dosages increase bacterial killing while longer dosing intervals are possible due to the long PAE.

\section{MECHANISM OF RESISTANCE}

Resistance to beta-lactams including carbapenems arises in one or a combination of three ways: beta-lactam hydrolysis by beta-lactamases, reduced permeability through the outer membrane (Gram-negatives only) and PBPs (6-8).

High level expression of carbapenem hydrolyzing betalactamases in $S$ maltophilia and occasionally in strains of Bacteroides species, $P$ aeruginosa and Serratia marcescens is associated with resistance to both meropenem and imipenem $(14,20,21,25)$. These metallo-beta-lactamases require zinc for maximal activity and exhibit a broad hydrolytic profile including carbapenems, penicillins and cephalosporins (21). Carbapenem-hydrolyzing beta-lactamases that preferentially hydrolyze carbapenems ('true carbapenemases'), are found in A hydrophila and, occasionally, in strains of Burkholderia cepacia (21).

The majority of published data describing carbapenem resistance concerns $P$ aeruginosa (26-28). Penicillins and cephalosporins, due to their low molecular weight and zwitterionic nature, readily penetrate the outer membrane of Gramnegative bacilli through porin proteins (29). The major porins involved are outer membrane proteins (OMPs) F and C. Carbapenems, however, use an unconventional route of entry, OMP $\mathrm{D}_{2}(27,30)$. Because carbapenems use a different entry mechanism and they are not very susceptible to hydrolysis by penicillinases and cephalosporinases, cross-resistance between carbapenems, and penicillins and cephalosporins does not occur (unless due to a carbapenem-hydrolyzing enzyme) (29). High level imipenem resistance in $P$ aeruginosa appears to be due to a combination of decreased uptake due to reduc- tion or lack of OMP $\mathrm{D}_{2}$, along with concomitant slow hydrolysis by beta-lactamases (26). Although the majority of data suggest cross-resistance between meropenem and imipenem, Gram-negative bacillary resistance due to reduced permeability is less of a concern with meropenem because meropenem is transported more rapidly through $\mathrm{OMP}_{2}(7)$. Finally, in a few species such as Enterococcus faecium (which uses PBP 5 and PBP 6 to make peptidoglycan) and methicillin-resistant $S$ aureus (MRSA) (which uses PBP 2a to make peptidoglycan), carbapenems do not readily bind to these PBPs, leading to resistance (29).

\section{IN VITRO ACTIVITY}

Susceptibility results (minimum inhibitory concentration of $90 \%$ of isolates $\left[\mathrm{MIC}_{90}\right]$ ) of meropenem and imipenem in comparison with common alternative antimicrobials against Gram-positive and Gram-negative aerobes, and anaerobes are listed in Tables 1 to $3(1,3-11,14,16-18,21,30-50)$. The values reflect the mean $\mathrm{MIC}_{90} \mathrm{~s}$ using standard susceptibility techniques for clinical isolates obtained worldwide.

Against Gram-positive aerobes, imipenem is in general two- to fourfold more active than meropenem (Table 1) $(1,3-11,16,17,30-40)$. Neither agent is active against MRSA or methicillin-resistant Staphlyococcus epidermidis. Imipenem is more active than meropenem against streptococcal species including Streptococcus pneumoniae. Penicillin-resistant $S$ pneumoniae are less sensitive to both imipenem and meropenem than penicillin-susceptible $S$ pneumoniae. Nevertheless, both imipenem and meropenem are active against penicillinresistant $S$ pneumoniae, with imipenem being fourfold more active than meropenem. Imipenem is fourfold more active than meropenem versus Enterococcus faecalis, and neither agent is active against $E$ faecium.

Generally, meropenem is two- to 16 -fold more active than imipenem against Gram-negative aerobes (Table 2) (1,3-11, 14,16-18,31-47). Against Enterobacteriaceae, meropenem is four- to 16 -fold more active than imipenem. Meropenem is approximately eightfold more active than imipenem against 
TABLE 2

Antibacterial activity (minimum inhibitory concentration of $90 \%$ of isolates $\mu \mathrm{g} / \mathrm{mL}$ ) of imipenem and meropenem in comparison with ceftazidime, piperacillin/tazobactam, gentamicin and ciprofloxacin against Gram-negative aerobes

\begin{tabular}{|c|c|c|c|c|c|c|}
\hline Gram-negative aerobes & Imipenem & Meropenem & Ceftazidime & Piperacillin/tazobactam & Gentamicin & Ciprofloxacin \\
\hline Acinetobacter anitratus & 0.25 & 1.0 & 8 & 16 & 1 & 8 \\
\hline Citrobacter freundii & 1 & 0.13 & 32 & 16 & 1 & 0.5 \\
\hline Enterobacter aerogenes & 1 & 0.13 & 16 & 32 & 1 & 0.25 \\
\hline Enterobacter cloacae & 1 & 0.25 & 16 & 32 & 8 & 0.25 \\
\hline Escherichia coli & 0.13 & 0.03 & 1 & 1 & 8 & 0.13 \\
\hline Haemophilus influenzae (BLN) & 0.5 & 0.06 & 0.06 & 0.13 & 8 & 0.016 \\
\hline Klebsiella species & 0.5 & 0.06 & 0.25 & 2 & 4 & 0.25 \\
\hline Moraxella catarrhalis & 0.06 & 0.008 & 0.5 & 2 & 2 & 0.06 \\
\hline Morganella morganii & 4 & 0.25 & 16 & 4 & 4 & 0.13 \\
\hline Neisseria gonorrhoeae (PS, PR) & 0.25 & 0.03 & 0.03 & 1 & 16 & 0.008 \\
\hline Neisseria meningitidis & 0.03 & 0.016 & 0.25 & 0.25 & 8 & 0.008 \\
\hline Providencia stuartii & 2 & 0.25 & 4 & 4 & 16 & 8 \\
\hline Pseudomonas aeruginosa & 4 & 2 & 8 & 8 & 16 & 2 \\
\hline Burkholderia cepacia & 8 & 8 & 16 & 128 & 128 & 8 \\
\hline Salmonella species & 0.12 & 0.03 & 0.5 & 2 & 0.5 & 0.06 \\
\hline Serratia marcescens & 2 & 0.25 & 4 & 2 & 16 & 2 \\
\hline Shigella species & 0.25 & 0.06 & 0.5 & 4 & 1 & 0.06 \\
\hline Stenotrophomonas maltophilia & 128 & 128 & 16 & 256 & 64 & 16 \\
\hline Yersinia enterocolitica & 0.25 & 0.03 & 0.5 & 2 & 2 & 0.13 \\
\hline
\end{tabular}

Adapted from references 1,3-11,14,16-18,31-47. In vitro susceptibility of imipenem and meropenem: susceptible $4 \mu \mathrm{g} / \mathrm{mL}$ or less, intermediate $8 \mu \mathrm{g} / \mathrm{mL}$, resistant $16 \mu \mathrm{g} / \mathrm{mL}$ or more. BLN Beta-lactamase negative; BLP Beta-lactamase positive; PR Penicillin-resistant; PS Penicillin-susceptible

TABLE 3

Antibacterial activity (minimum inhibitory concentration of $90 \%$ of isolates $\mu \mathrm{g} / \mathrm{mL}$ ) of imipenem and meropenem in comparison with cefoxitin, clindamycin and metronidazole against anaerobes

\begin{tabular}{lccccc}
\hline Anaerobes & Imipenem & Meropenem & Cefoxitin & Clindamycin & Metronidazole \\
\hline Bacteroides fragilis & 0.5 & 0.25 & 16 & 32 & 2 \\
B fragilis group & 1 & 0.5 & 2 & 16 & 2 \\
Clostridium difficile & 8 & 0.12 & 0.5 & 2 & 2 \\
Clostridium perfringens & 0.5 & 0.5 & 2 & 2 & 2 \\
Fusobacterium species & 0.5 & 0.5 & 2 & 2 & 32 \\
Peptostreptococcus species & 0.25 & & 2 & 32 \\
\hline
\end{tabular}

Adapted from references 1,3,5-8,21,34,36,48-50. In vitro susceptibility of imipenem and meropenem: susceptible $4 \mu \mathrm{g} / \mathrm{mL}$ or less, intermediate $8 \mu \mathrm{mg} / \mathrm{mL}$, resistant $16 \mu \mathrm{g} / \mathrm{mL}$ or more

Haemophilus influenzae and Neisseria gonorrhoeae. B cepacia displays intermediate resistance, and $S$ maltophilia is resistant to both agents.

Meropenem and imipenem are active against most strains of clinically significant anaerobes (Table 3) (1,3,5-8,21, $34,36,48-50)$. Both agents demonstrate similar activity against $B$ fragilis and Bacteroides group organisms. In addition, they demonstrate similar activity against Gram-positive anaerobes.

Both imipenem and meropenem are more active than ceftazidime, gentamicin or ciprofloxacin, and similarly active to piperacillin/tazobactam against Gram-positive aerobes. All of the antimicrobials listed in Table 2 have potent activity against Gram-negative aerobes. Imipenem and meropenem have very good anaerobic activity along with metronidazole, clindamycin, cefoxitin and piperacillin/tazobactam.

\section{PHARMACOKINETICS}

Pharmacokinetic profiles of imipenem and meropenem in healthy volunteers are shown in Table 4 (51-64). Imipenem and meropenem are not absorbed orally; however, after intravenous administration, both antimicrobials achieve peak serum concentrations far in excess of reported MICs for most 
TABLE 4

Pharmacokinetic comparison of imipenem and meropenem

\begin{tabular}{|c|c|c|}
\hline Parameter & Imipenem & Meropenem \\
\hline Orally absorbed & No & No \\
\hline $\mathrm{Vd}_{\mathrm{sS}}$ & $0.25 \mathrm{~L} / \mathrm{kg}$ & 0.23 to $0.35 \mathrm{~L} / \mathrm{kg}$ \\
\hline $\mathrm{C}_{\max }(500 \mathrm{mg}$ infusion, adult) & $33 \mu \mathrm{g} / \mathrm{mL}$ & $26 \mu \mathrm{g} / \mathrm{mL}$ \\
\hline $\mathrm{C}_{\max }(1 \mathrm{~g}$ dose infusion, adult $)$ & $52 \mu \mathrm{g} / \mathrm{mL}$ & $49 \mu \mathrm{g} / \mathrm{mL}$ \\
\hline $\mathrm{C}$ (6 h after $1 \mathrm{~g}$ dose, adult) & $1 \mu \mathrm{g} / \mathrm{mL}$ & - \\
\hline $\mathrm{C}$ (8 $\mathrm{h}$ after $1 \mathrm{~g}$ dose, adult) & - & $0.25 \mu \mathrm{g} / \mathrm{mL}$ \\
\hline $\begin{array}{l}\text { Half-life (normal renal function, } \\
\text { adult) }\end{array}$ & $1 \mathrm{~h}$ & $1 \mathrm{~h}$ \\
\hline $\begin{array}{l}\mathrm{C}_{\max }(20 \mathrm{mg} / \mathrm{kg} \text {, children } \\
\text { younger age } 12 \text { years })\end{array}$ & - & $62 \mu \mathrm{g} / \mathrm{mL}$ \\
\hline $\begin{array}{l}\text { Half-life (normal renal function, } \\
\text { children younger than } 12 \\
\text { years) }\end{array}$ & - & $1 \mathrm{~h}$ \\
\hline Plasma protein binding & $20 \%$ & $2 \%$ \\
\hline Renal elimination as parent & $\begin{array}{c}60 \% \text { to } 70 \% \\
\text { (with cilastatin) }\end{array}$ & $70 \%$ \\
\hline Active metabolite & No & No \\
\hline
\end{tabular}

Adapted from references 51-64. $V d_{\mathrm{ss}}$ Volume of distribution at steady state; $C$ Serum concentration; $C_{\max }$ Maximum concentration in plasma

TABLE 5

Imipenem: Dose adjustment in renal dysfunction*

\begin{tabular}{lcc}
\hline $\begin{array}{l}\text { Creatine clearance } \\
\left(\mathbf{m L} / \mathbf{m i n} / \mathbf{1 . 7 3} \mathbf{~}^{\mathbf{2}}\right)\end{array}$ & Dose & Dosing interval \\
\hline 31 to 70 & $500 \mathrm{mg}$ & Every 6 to $8 \mathrm{~h}$ \\
21 to 30 & $500 \mathrm{mg}$ & Every 8 to $12 \mathrm{~h}$ \\
0 to 20 & 250 to $500 \mathrm{mg}$ & Every $12 \mathrm{~h}$ \\
\hline
\end{tabular}

*Manufacturer's recommendations: Imipenem/Cilastatin product monograph. Rahway: Merck Sharpe and Dohme, 1985

Gram-positive, Gram-negative and anaerobic organisms (Tables 1-3) (51-54).

Like imipenem, meropenem distributes well into most bodily fluids (52,55-57). Hextall et al (58) reported that the intraperitoneal penetration of meropenem was $95 \%$ of the corresponding area under the curve (AUC) in plasma $2 \mathrm{~h}$ after a single intravenous infusion (58). In patients with meningitis, imipenem cerebrospinal fluid (CSF) concentrations of 0.5 to $11 \mu \mathrm{g} / \mathrm{mL}$ have been reported upon repeated dosing of $1 \mathrm{~g}$ every $6 \mathrm{~h}$ (59). Meropenem also appears to penetrate well into the CSF in the presence of inflamed meninges. Dagan et al (57) conducted a trial in 23 patients with bacterial or viral meningitis already receiving antimicrobial treatment. Patients receiving a single intravenous infusion of meropenem $20 \mathrm{mg} / \mathrm{kg}$ or $40 \mathrm{mg} / \mathrm{kg}$ achieved CSF concentrations of 0.1 to $2.8 \mu \mathrm{g} / \mathrm{mL}$ and 0.3 to $6.5 \mu \mathrm{g} / \mathrm{mL}$, respectively. There was significant interpatient variability highlighted by CSF to plasma concentration ratios from $1 \%$ to $42 \%$ and from $2 \%$ to $52 \%$, respectively (57). It should be mentioned that because CSF to plasma concentration ratios can show considerable variation, AUC comparisons between CSF and plasma are more likely to represent the true degree of penetration of an antibiotic into CSF.

Imipenem is hydrolyzed by renal dehydropeptidase- 1 enzymes located on the brush border of the proximal renal tubules. Administration with cilastatin prevents imipenem
TABLE 6

Meropenem: Dose adjustment in renal dysfunction*

\begin{tabular}{lcc}
\hline $\begin{array}{l}\text { Creatine clearance } \\
\left(\mathbf{m L} / \mathbf{m i n} / \mathbf{1 . 7 3} \mathbf{~ m}^{\mathbf{2}}\right)\end{array}$ & Dose & Dosing interval \\
\hline 51 or greater & $\begin{array}{c}500 \mathrm{mg} \text { to } 2 \mathrm{~g} \\
\text { (ie, recommended dose) }\end{array}$ & Every $8 \mathrm{~h}$ \\
26 to 50 & Recommended dose & Every $12 \mathrm{~h}$ \\
10 to 25 & $1 / 2$ recommended dose & Every $12 \mathrm{~h}$ \\
Less than 10 & $1 / 2$ recommended dose & Every $24 \mathrm{~h}$ \\
\hline
\end{tabular}

*Manufacturer's recommendations: Meropenem product monograph. Mississauga: Zeneca Pharma Inc, 1996

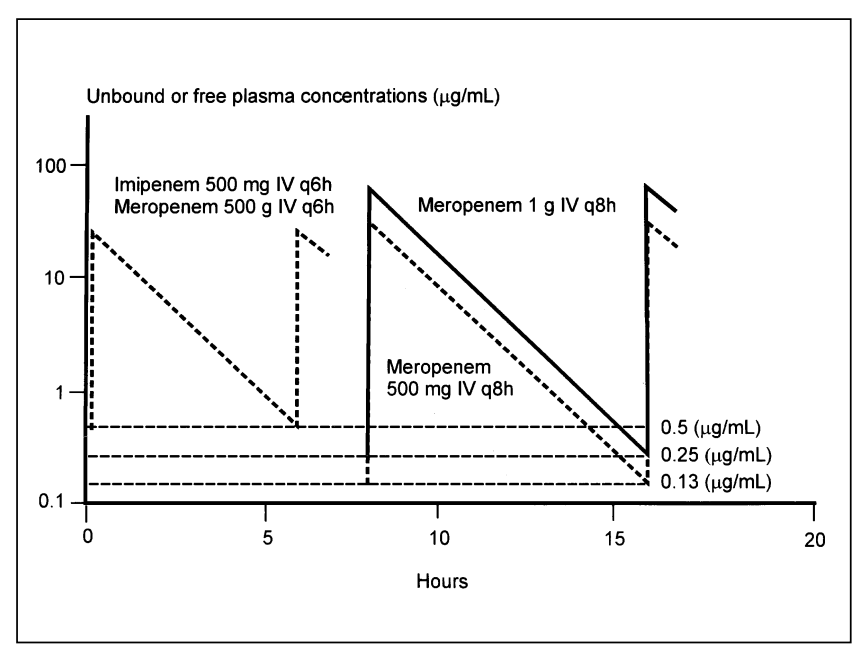

Figure 2) Plasma concentration-time profile comparisons for steadystate dosing regimens of imipenem and meropenem. IV Intravenous; q Every

destruction by dehydropeptidase and potential nephrotoxicity that occurs due to the metabolites. Sixty to seventy per cent of imipenem is excreted unchanged in the urine in the presence of cilastatin. Approximately $70 \%$ of meropenem is renally eliminated as the parent compound.

Because of extensive renal elimination, doses of both imipenem and meropenem must be adjusted in renal dysfunction. Imipenem's half-life increases to $4 \mathrm{~h}$ and meropenem's to $7 \mathrm{~h}$ in patients with creatinine clearances less than $10 \mathrm{~mL} / \mathrm{min}$ (Table 4). Both imipenem and meropenem are removed by dialysis, therefore supplemental doses (regimen based on infection and severity) should be administered after dialysis $(60,54)$. Tables 5 and 6 summarize the recommended dose changes for imipenem and meropenem, respectively, in patients with renal dysfunction. Neither antimicrobial undergoes appreciable hepatic metabolism, therefore no dose adjustment is necessary in patients with hepatic dysfunction.

Pharmacokinetic studies conducted in other disease states, including surgical patients with moderate or severe infections and patients with intra-abdominal infections, report no clinically significant changes in pharmacokinetic parameters and do not require specific dose adjustments $(55,56)$.

Figure 2 demonstrates the average plasma concentrationtime profiles for various steady-state dosing regimens of impenem and meropenem. The enhanced activity of meropenem against Enterobacteriaceae species allows for an extension in 
TABLE 7

Imipenem verus selected antibiotics for treatment of serious infections in hospitalized patients

\begin{tabular}{|c|c|c|c|c|c|c|}
\hline $\begin{array}{l}\text { Study } \\
\text { (reference) }\end{array}$ & Design & $\begin{array}{l}\text { Patients } \\
\text { (clinically evalu- } \\
\text { able patients) }\end{array}$ & Indication & Regimen & Duration* & Results \\
\hline $\begin{array}{l}\text { Solomkin et al } \\
\text { (75) }\end{array}$ & $\begin{array}{l}\text { Prospective, } \\
\text { randomized, } \\
\text { open }\end{array}$ & $290(162)$ & $\begin{array}{l}\text { Intra-abdominal } \\
\text { infections }\end{array}$ & $\begin{array}{l}\text { I: } 500 \mathrm{mg} \text { every } 6 \mathrm{~h} \\
\text { Clinda: } 600 \mathrm{mg} \text { every } \\
6 \mathrm{~h} \text { and Tobra: } 1.5 \mathrm{mg} / \mathrm{kg} \\
\text { (adjusted to peak } \\
\geq 6 \mu \mathrm{g} / \mathrm{mL} \text {, trough } 1 \text { to } \\
2 \mu \mathrm{g} / \mathrm{mL} \text { ) }\end{array}$ & NR & $\begin{array}{l}\text { I: success }{ }^{\dagger}: 67 / 81(83 \%) \\
\text { Clinda/Tobra: } \\
\text { success:57/81 (70\%) } \\
P=0.043\end{array}$ \\
\hline Fink et al (84) & $\begin{array}{l}\text { Prospective, } \\
\text { randomized, } \\
\text { double-blind }\end{array}$ & 402 (205) & $\begin{array}{l}\text { Severe pneumonia } \\
\text { (primarily } \\
\text { intensive care } \\
\text { unit) }\end{array}$ & $\begin{array}{l}\text { I: } 1 \text { g every } 8 \mathrm{~h} \text { ( } 500 \text { mg } \\
\text { every } 6 \mathrm{~h} \text { for highly sus- } \\
\text { ceptible pathogens) } \\
\text { Cipro: } 400 \mathrm{mg} \text { IV every } 8 \mathrm{~h} \\
\text { (400 mg every } 12 \mathrm{~h} \text { for } \\
\text { highly susceptible patho- } \\
\text { gens) }\end{array}$ & 10.5 days & $\begin{array}{l}\text { Efficacy evaluable } \\
\text { I: } 58 / 104(56 \%) \\
\text { Cipro: } 68 / 98(69 \%) \\
\mathrm{P}=0.021 \\
\text { Intent to treat } \\
\text { I: } 90 / 162(56 \%) \\
\text { Cipro: } 92 / 144(64 \%) \\
P=0.123\end{array}$ \\
\hline $\begin{array}{l}\text { Norrby et al } \\
(87)\end{array}$ & $\begin{array}{l}\text { Prospective, } \\
\text { randomized, } \\
\text { single-blind } \\
\text { (septicemia } \\
\text { subgroup) }\end{array}$ & $91(66)$ & Septicemia & $\begin{array}{l}\text { I: } 500 \text { mg every } 6 \mathrm{~h} \\
\text { Ceft: } 2 \text { g every } 12 \mathrm{~h}\end{array}$ & $\begin{array}{l}9.7 \text { days } \\
8.8 \text { days }\end{array}$ & $\begin{array}{l}\text { I: } 26 / 32(81 \%)^{* *} \\
\text { Ceft: } 25 / 34(74 \%)^{* *} \text { (not } \\
\text { statistically significant, } \\
\text { no P reported) }\end{array}$ \\
\hline $\begin{array}{l}\text { Cornelissen } \\
\text { et al (101) }\end{array}$ & $\begin{array}{l}\text { Prospective, } \\
\text { randomized, } \\
\text { open }\end{array}$ & $\begin{array}{l}87 \text { (94 evaluable } \\
\text { febrile } \\
\text { episodes) }\end{array}$ & $\begin{array}{l}\text { Febrile } \\
\text { neutropenia }\end{array}$ & $\begin{array}{l}\text { I: } 500 \text { mg every } 6 \mathrm{~h} \\
\text { Gent: } 80 \text { mg every } 8 \mathrm{~h} \\
\text { and cefuroxime: } 1.5 \mathrm{~g} \\
\text { every } 8 \mathrm{~h}(\mathrm{n}=35) \text { or } \\
\text { Cephalothin } 1 \mathrm{~g} \text { every } 4 \mathrm{~h} \\
(\mathrm{n}=12) \\
\text { (Note: } 65 \% \text { of patients on } \\
\text { cipro prophylaxis) }\end{array}$ & $\begin{array}{l}\text { At least } 7 \text { days } \\
\text { for initial } \\
\text { responders }\end{array}$ & $\begin{array}{l}\text { I: } 43 / 49(91 \%)^{\S \S} \\
\text { Gent + cefuroxime or } \\
\text { cephalothin: } 35 / 47 \\
(74 \%)^{\S \S} \\
\mathrm{P}=0.05\end{array}$ \\
\hline $\begin{array}{l}\text { Liang et al } \\
\text { (102) }\end{array}$ & $\begin{array}{l}\text { Prospective, } \\
\text { randomized, } \\
\text { open }\end{array}$ & $\begin{array}{l}89 \text { (100 } \\
\quad \text { evaluable } \\
\text { fever episodes) }\end{array}$ & $\begin{array}{l}\text { Febrile } \\
\text { neutropenia }\end{array}$ & $\begin{array}{l}\text { I: } 500 \text { mg every } 6 \mathrm{~h} \\
\text { Ceft: } 2 \text { g every } 8 \mathrm{~h}\end{array}$ & $\begin{array}{l}\text { At least } 7 \text { days for } \\
\text { initial respond- } \\
\text { ers, or } 4 \text { days } \\
\text { postfebrile } \\
\text { episode }\end{array}$ & $\begin{array}{l}\text { I: } 37 / 48(77 \%)^{\text {ศा }} \\
\text { Ceft: } 29 / 52(56 \%)^{\text {ศा }} \\
\mathrm{P}=0.04\end{array}$ \\
\hline
\end{tabular}

\footnotetext{
*Mean number of days of treatment. "Success" defined as initial intervention resolved the intra-abdominal infectious process with no infectious wound complications. *"Resolution of the infection without additional antimicrobials". \$Cured or improved at four to 14 days post-therapy. "Disappearance of signs and symptoms related to the infection three to seven days after completion of therapy. ${ }^{*}$ Clinical signs and symptoms subside with complete resolution of active infection. ${ }^{+t}$ Response defined as temperature less than $37.5^{\circ} \mathrm{C}$ for $48 \mathrm{~h} .{ }^{* \neq}$ Response defined as temperature less than $37.5^{\circ} \mathrm{C}$ to $38^{\circ} \mathrm{C}$ based on initial response at $72 \mathrm{~h}$. ${ }^{\mathcal{S}}$ Response defined as improvement or resolution of signs and symptoms of infection with no need for other antimicrobials. ${ }^{\text {IT }}$ Response to initial monotherapy defined as complete disappearance of all clinical and laboratory evidence of infection including fever. Ceft Ceftazidime; Cipro Ciprofloxacin; Clinda Clindamycin; Gent Gentamicin; I Imipenem; IV Intravenous; Metro Metronidazole; NR Not reported; Pip Piperacillin; Tazo Tazobactam; Tobra Tobramycin
} 
TABLE 8

Meropenem versus selected antibiotics for treatment of serious infections in hospitalized patients

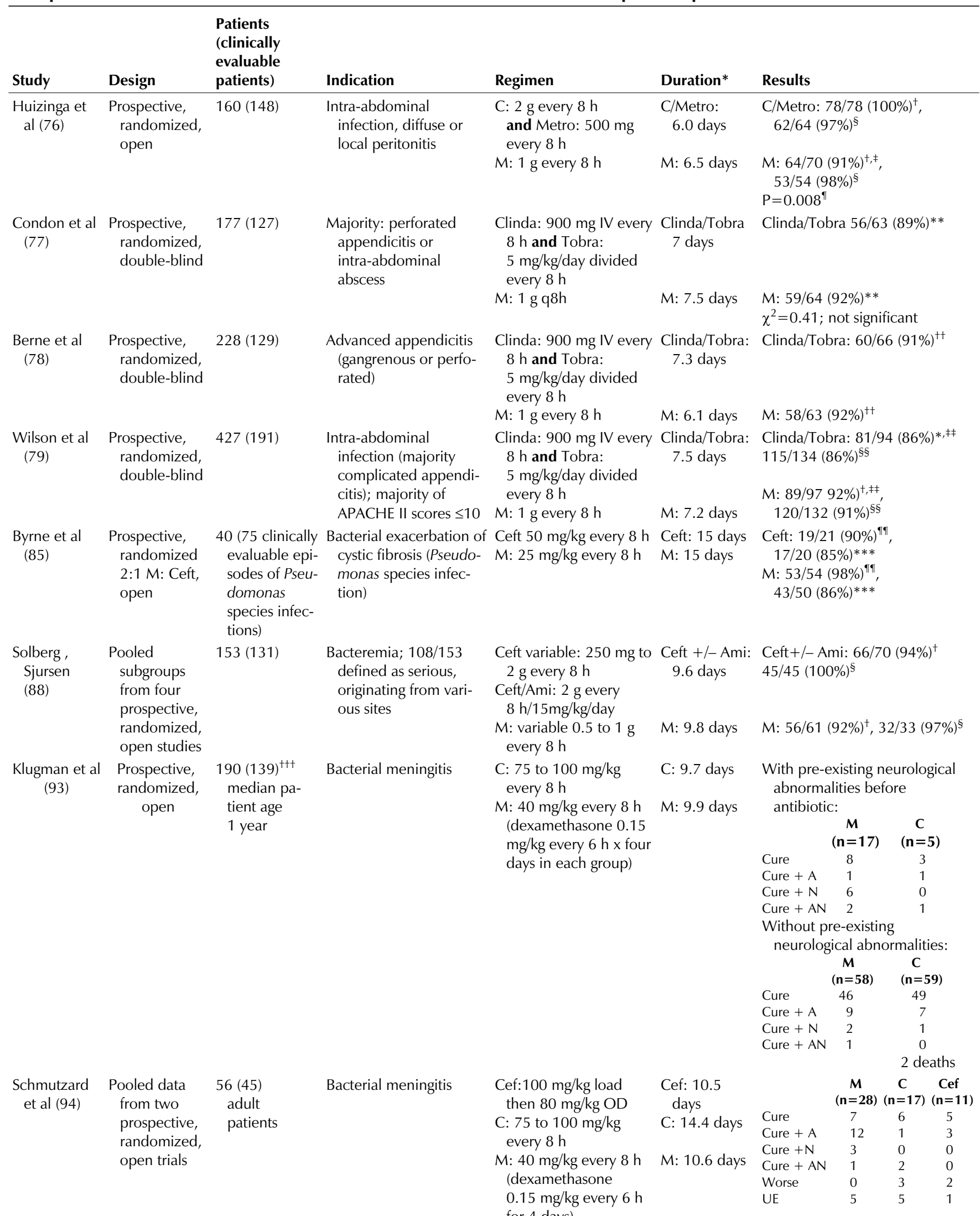


TABLE 8 continued

Meropenem versus selected antibiotics for treatment of serious infections in hospitalized patients

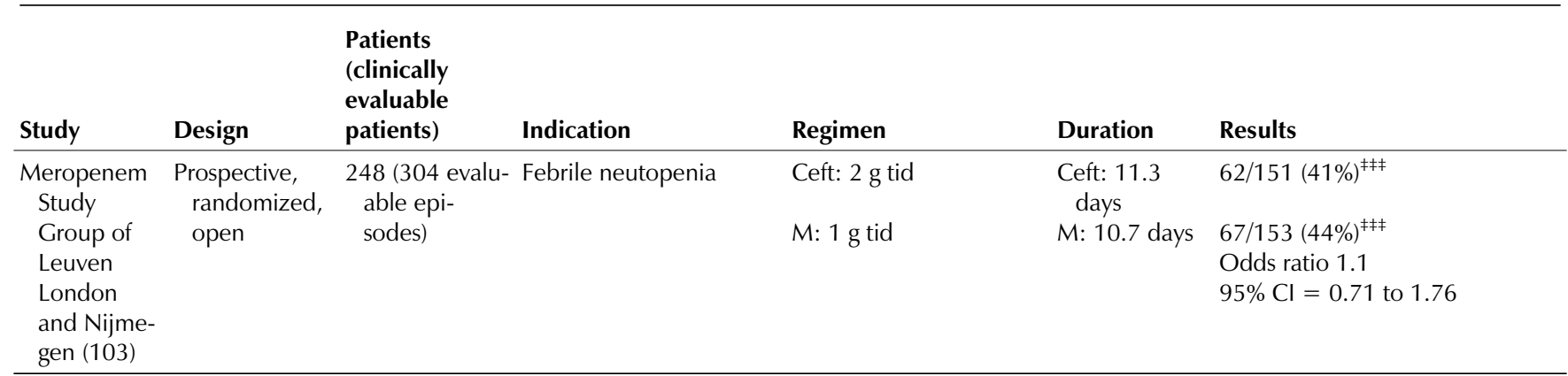

${ }^{*}$ Mean number of treatment days. ${ }^{+}$Clinically cured or improved at end of therapy. ${ }^{\ddagger}$ Three failures attributed to "surgical misadventure". ${ }^{\$}$ Clinically cured or improved at two to four weeks follow-up. "Statistically significant difference at end of therapy. **"Success" defined as no clinical evidence of infection at any body site at the completion of antibiotic therapy, no relapse of abdominal infection during follow-up (28 to 42 days posthospitalization) and no adverse drug reaction requiring termination. ${ }^{+t}$ "Failure" defined as subsequent development of intra-abdominal abscesses, persistent or recurrent clinical signs of infec-

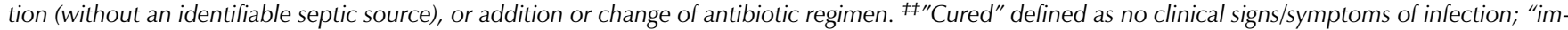
proved" defined as significant abatement of signs and symptoms of infection. \$\& Intent-to-treat analyses. "Ti" "Satisfactory response" defined as improvement in lung function, ease of breathlessness, weight gain and general well-being at end of therapy. *** "Satisfactory response" defined as improvement in lung function, ease of breathlessness, weight gain and general well-being at follow-up in four to six weeks. ${ }^{+++}$Cerebrospinal fluid culture confirmed bacterial meningitis included for efficacy analysis. ${ }^{\neq \neq \neq} A l l$ signs and symptoms of infection resolved without modification of empirical regimen (ie, addition of antifungal or modification of the antibiotic regimen). C Cefotaxime; $c+$ A Cure with audiological sequelae; $c+$ AN Cure with audiological and neurological sequelae; $c+N$ Cure with neurological sequelae; Cef Ceftriaxone; Ceft Ceftazidime; Ceft/Ami Ceftazidime and amikacin; Clinda Clindamycin; IV Intravenous; M Meropenem; Metro Metronidazole; OD Once daily; Tobra Tobramycin; UE Unevaluable

the dosing interval to every $8 \mathrm{~h}$ compared with every $6 \mathrm{~h}$ for imipenem. Whether the increased activity of imipenem over meropenem against Gram-positive cocci allows the imipenem dosing interval to be extended to every $8 \mathrm{~h}$ is unclear. For the average patient, the dosing regimen for meropenem of $1 \mathrm{~g}$ every $8 \mathrm{~h}$ provides for trough concentrations of approximately $0.25 \mu \mathrm{g} / \mathrm{mL}$ (Figure 2), while $500 \mathrm{mg}$ every $8 \mathrm{~h}$ provides for trough concentrations around $0.13 \mu \mathrm{g} / \mathrm{mL}$ and a lower peak concentration. Whether the slightly lower peak and trough concentrations (with $500 \mathrm{mg}$ every $8 \mathrm{~h}$ ), and $1 \mathrm{~h}$ less time above the MIC than $1 \mathrm{~g}$ every $8 \mathrm{~h}$ result in clinically significant differences in bacteriological or clinical outcome is unknown. It would, however, appear that $500 \mathrm{mg}$ every $6 \mathrm{~h}$ of meropenem would provide trough serum concentrations higher than when using $500 \mathrm{mg}$ every $8 \mathrm{~h}$ of meropenem and similar to those using $500 \mathrm{mg}$ every $6 \mathrm{~h}$ of imipenem.

\section{CLINICAL TRIALS}

Many comparative trials have been published using imipenem or meropenem for the treatment of serious infections in hospitalized patients. This review focuses on the comparison of imipenem with meropenem, and the comparison of either agent with standard therapy for potentially life-threatening infections including intra-abdominal infections, respiratory infections, septicemia, bacterial meningitis and febrile neutropenia. Imipenem and meropenem are most likely to be used in the treatment of serious infections. Only prospective, randomized trials published in peer reviewed journals were considered, and are summarized in Tables 7 to 9. Abstracts presented before 1994 without subsequent publication were not included.

Although the trials were prospective and randomized, no direct comparisons of imipenem and meropenem were double-blinded (65-68). In addition, none of the trials compar- ing imipenem with meropenem demonstrated a statistically significant difference between treatment groups. Although two of three $(67 \%)$ of the trials listed in Table 9 had a total sample size of more than 200 patients, approximately $140 \mathrm{pa}$ tients per arm would be required to show a statistically significant difference if a $10 \%$ difference in cure rate existed (assuming the proportion of subjects expected to have clinical cure is $0.85, \alpha=0.05, \beta=0.20$ ) (69). None of the three studies presented had the required number of patients per arm.

\section{INTRA-ABDOMINAL INFECTIONS}

Imipenem: Several clinical trials have compared imipenem with various antimicrobial combinations effective against a combination of anaerobic and aerobic bacteria for the treatment of intra-abdominal infections (70-75). Solomkin et al (75) reported a clinically and statistically significant improvement in favour of imipenem (83\%) over a combination of clindamycin/tobramycin $(70 \%)$ for the resolution of intraabdominal infections. Differences were explained by a high failure rate in patients with Gram-negative organisms (primarily $E$ coli and Enterobacter species) and an increased incidence of fasciitis requiring operative debridement for patients in the tobramycin/clindamycin group (75). Eklund et al (72) conducted a prospective, randomized, open trial comparing piperacillin/tazobactam (4 g/500 mg every $8 \mathrm{~h}$ ) with imipenem $(500 \mathrm{mg}$ every $8 \mathrm{~h}$ ) for treatment of severe intra-abdominal infections (72). Although piperacillin/tazobactam was statistically more effective than imipenem ( $91 \%$ cured versus $69 \%$, respectively), the dose of imipenem was smaller than the currently recommended doses for serious infections (72). All trials investigating intra-abdominal infections presented in Table 7 used imipenem at doses of $500 \mathrm{mg}$ every $6 \mathrm{~h}$ or $1 \mathrm{~g}$ every $8 \mathrm{~h}$. Other trials investigating intra-abdominal infections demonstrated no statistically significant difference between imipe- 
TABLE 9

Direct comparisons of imipenem and meropenem for treatment of serious infections in hospitalized patients

\begin{tabular}{|c|c|c|c|c|c|c|}
\hline Study & Design & $\begin{array}{l}\text { Number of } \\
\text { patients enrolled } \\
\text { in study }\end{array}$ & Indication & Regimen & Duration* & Results \\
\hline $\begin{array}{l}\text { Kanellakopoulou } \\
\text { et al (65) }\end{array}$ & $\begin{array}{l}\text { Prospective, } \\
\text { randomized, } \\
\text { open }\end{array}$ & 62 & $\begin{array}{l}\text { Diffuse or local } \\
\text { peritonitis }\end{array}$ & $\begin{array}{l}\mathrm{I}: 1 \mathrm{~g} \text { every } 8 \mathrm{~h} \\
\text { versus } \\
\mathrm{M}: 1 \mathrm{~g} \text { every } 8 \mathrm{~h}\end{array}$ & $\begin{array}{l}8.6 \text { days } \\
7.7 \text { days }\end{array}$ & $\begin{array}{l}\text { 30/31 }(96.8 \%)^{\dagger}, \\
29 / 31(93.5 \%)^{\ddagger} \\
28 / 28(100 \%)^{\dagger}, \\
27 / 28(96.4 \%)^{\ddagger} \\
\mathrm{P}=\text { "not significant" }\end{array}$ \\
\hline Brismar et al (67) & $\begin{array}{l}\text { Prospective, } \\
\text { randomized, } \\
\text { open }\end{array}$ & 249 & $\begin{array}{l}\text { Primarily "low risk" } \\
\text { intra-abdominal } \\
\text { infection (APACHE } \\
\text { II=0-10) }\end{array}$ & $\begin{array}{l}\text { I: } 500 \mathrm{mg} \text { every } 8 \mathrm{~h} \\
\text { versus } \\
\text { M: } 500 \mathrm{mg} \text { every } 8 \mathrm{~h}\end{array}$ & $\begin{array}{l}5.1 \text { days } \\
5.4 \text { days }\end{array}$ & $\begin{array}{l}86 / 90(96 \%)^{+\dagger} \\
97 / 99(98 \%)^{+\dagger} \\
P=0.342^{* *}\end{array}$ \\
\hline
\end{tabular}

*Mean number of days of treatment. ${ }^{\dagger}$ Clinical "cure" at the end of therapy. ${ }^{\ddagger}$ Clinical "cure" at follow-up longer than 30 days. ${ }^{\S}$ Significant clinical response defined as "cure or improvement" at the end of therapy; "cure" defined as complete resolution of signs and symptoms of infection without addition of antibiotics or recurrence of symptoms; "improvement" defined as significant improvement in signs and symptoms without complete resolution of infection but allowing study treatment to be stopped. "Significant clinical response defined as "cure or improvement" at two to four weeks' follow-up. **Not statistically significant (for results at end of therapy). ${ }^{t \prime}$ "Cure" defined as complete remission of signs and symptoms of infection without further surgical intervention, addition of other antibiotics and without recurrence of symptoms. I Imipenem; M Meropenem

nem and piperacillin/tazobactam or tobramycin plus clindamycin (or metronidazole) $(73,74)$.

Meropenem: In an open trial conducted by Huizinga et al (76) for the treatment of intra-abdominal infections, cefotaxime plus metronidazole achieved a significantly higher cure rate than meropenem ( $100 \%$ versus $91 \%$, respectively; $\mathrm{P}=0.008)$ (Table 8). Clinically, both agents achieved a cure rate higher than $90 \%$, and three of the failures in the meropenem group were attributed to 'surgical misadventure'. Bacteriological cure rates were not significantly different ( $92 \%$ versus $90 \%$, respectively) (76).

Prospective, randomized, double-blind studies conducted by Condon et al (77) and Berne et al (78) reported no significant difference in clinical cure rates when clindamycin $(900$ intravenous every $8 \mathrm{~h}$ ) and tobramycin $(5 \mathrm{mg} / \mathrm{kg} /$ day divided every $8 \mathrm{~h}$ ) were compared with meropenem ( $1 \mathrm{~g}$ every $8 \mathrm{~h}$ ) for the treatment of serious intra-abdominal infections $(77,78)$. Most recently, Wilson (79) confirmed the similar clinical cure rates of meropenem ( $1 \mathrm{~g}$ intravenous every $8 \mathrm{~h}$ ) compared with clindamycin ( $900 \mathrm{mg}$ intravenous every $8 \mathrm{~h}$ ) plus tobramycin ( $5 \mathrm{mg} / \mathrm{kg} /$ day in three divided doses) for treatment of intraabdominal infections (Table 8).

Imipenem versus meropenem: All trials presented in Table 9 comparing imipenem with meropenem for treatment of low risk to severe intra-abdominal infections were prospective, randomized, open trials (65-67). Doses used were $1 \mathrm{~g}$ every $8 \mathrm{~h}$ in all cases except for the study conducted by Brismar et al (67) with low risk patients, which used $500 \mathrm{mg}$ every $8 \mathrm{~h}$. No clinically or statistically significant difference was reported between imipenem and meropenem in any of the trials, all of which achieved cure rates higher than 90\% (65-67).

\section{RESPIRATORY TRACT INFECTIONS}

Imipenem: Imipenem has been studied extensively for the treatment of severe lower respiratory tract infections (80-84). In the largest prospective, randomized, double-blind trial of clinically evaluable patients with severe pneumonia, Fink et al (84) reported a significantly higher clinical response rate with ciprofloxacin compared with imipenem (69\% versus $56 \%$, respectively; $\mathrm{P}=0.021$ ) (Table 7 ). The subsequent intent-to-treat analysis showed a greater clinical response rate in favour of ciprofloxacin that was not statistically significant (64\% versus $56 \%, \mathrm{P}=0.123$ ). Bacteriological eradication rates were higher in patients treated with ciprofloxacin $(76 \%)$ than treated with imipenem (68\%), a result that was primarily attributed to a superior eradication of Enterobacteriaceae. The isolation of $P$ aeruginosa from initial respiratory tract cultures was associated with failure to achieve bacteriological eradication in $67 \%$ of patients receiving ciprofloxacin and 59\% receiving imipenem. Development of resistance to $P$ aeruginosa occurred during therapy in $33 \%$ and $53 \%$ of patients treated with ciprofloxacin and imipenem, respectively (84). Krilov et al (82) also reported that $P$ aeruginosa rapidly developed resistance to imipenem in 11 of 19 patients treated for acute pulmonary exacerbations of cystic fibrosis. Monotherapy with imipenem should be discouraged in the treatment of severe lower respiratory tract infections if $P$ aeruginosa is isolated.

Meropenem: No prospective, randomized trials specifically regarding treatment for pneumonia are available. Byrne et al (85) conducted a prospective, randomized, open trial to determine the efficacy of meropenem compared with ceftazidime for the treatment of Pseudomonas species infections in cystic fibrosis patients (Table 8). Meropenem produced a "satisfactory 
response", defined as improvement in lung function, ease of breathlessness, weight gain and general well-being in $98 \%$ of 54 evaluable episodes. Monotherapy with ceftazidime produced a $90 \%$ success rate in 21 evaluable episodes. Total bacterial counts were reduced by $73 \%$ in the meropenem group $(n=59)$ and by $65 \%$ in the ceftazidime group $(n=20)$. No statistical analysis was performed. Although this study had an open design with a small sample size, a 98\% "satisfactory response" suggests that meropenem may show promise as an effective treatment option for Pseudomonas species infections in patients with cystic fibrosis (85).

Imipenem versus meropenem: Comparisons of imipenem versus meropenem for respiratory tract infections are limited to acute bacterial exacerbations of chronic obstructive pulmonary disease. Although Hamacher et al (68) reported "cure or improvement" rates greater than $95 \%$ with either antibiotic, the authors absolutely do not recommend the use of either carbapenem for acute exacerbations of chronic bronchitis.

\section{BACTEREMIA}

Imipenem: There are a limited number of clinical trials investigating the efficacy of imipenem in the treatment of bacteremia $(86,87)$. Thirty-four patients requiring admission to the intensive care unit for treatment of bacteremia were studied by Linton et al (86) in a prospective, open, noncomparative trial. Imipenem doses ranging from 2 to $3 \mathrm{~g}$ /day in divided doses achieved a clinical cure in 28 of 34 patients (82\%) and bacteriological eradication in 24 of 34 patients (71\%) (86). In a more rigorous prospective, randomized, single-blind trial of serious hospital-acquired infections, Norrby et al (87) compared imipenem (500 mg every $6 \mathrm{~h}$ ) and ceftazidime ( 2 g every $12 \mathrm{~h}$ ) (Table 7). Ninety-one of 393 patients were diagnosed with septicemia (defined as clinical deterioration and rigors in association with unstable hemodynamic parameters and/or coagulopathy consistent with sepsis with or without bacteremia), of which 66 were clinically evaluable. There was no statistically significant difference between treatment groups, with $81 \%$ of imipenem patients and $74 \%$ of ceftazidime patients achieving a complete resolution of active infection (87). E coli, Klebsiella species and $P$ aeruginosa were the most commonly isolated organisms. Overall, there was "no significant difference" in bacteriological eradication rates between the treatment groups in septic patients ( $\mathrm{P}$ value was not provided).

Meropenem: Ceftazidime with or without amikacin was compared with meropenem for the treatment of 153 patients with bacteremia (Table 8 ). Solberg and Sjursen (88) pooled the results of four prospective, randomized, open trials using a common protocol. There was no clinically significant difference between the treatment groups, with a clinical response rate of $92 \%$ in the meropenem group $(n=61)$ and $94 \%$ in the ceftazidime with or without amikacin group $(n=70)$ at the end of therapy (88). No statistical analysis was performed. Although a common protocol was used in all four studies, there is potential for variability in pooled results if the protocols were not followed in precisely the same fashion among studies (89).

Imipenem versus meropenem: No direct comparative, pro- spective, randomized trials have been published comparing imipenem with meropenem.

\section{BACTERIAL MENINGITIS}

Imipenem: Although imipenem has been investigated for the treatment of bacterial meningitis, development of seizures has been a concern in trials conducted thus far (90-92). In a small, prospective, noncomparative, open trial $(n=21)$, Wong et al (91) reported a $33 \%$ incidence of seizures after administration of imipenem ( $25 \mathrm{mg} / \mathrm{kg}$ every $6 \mathrm{~h}$ ) in children without seizures before therapy. This incidence is much higher than that reported in postmarketing surveillance of all indications $(1.5 \%$ to 2\%) (92).

Meropenem: Meropenem has proven to be effective in the treatment of bacterial meningitis in clinical trials. Prospective, randomized, open studies conducted by Klugman and Dagnan (93) and Schmutzard et al (94) reported clinical cure with and without audiological and neurological sequelae in all clinically evaluable patients treated with meropenem (Table 8 ). In the largest of the two studies, 139 of 190 children had positive pretherapy CSF cultures. Of these, 121 (63 in the meropenem group and 58 in the cefotaxime group) underwent repeat lumbar puncture within 18 to $36 \mathrm{~h}$, with a bacterial eradication rate of greater than $95 \%$ in both groups (93). Overall, in patients with no pre-existing seizures before therapy, seizures occurred in five of 82 patients $(6 \%)$ receiving meropenem and one of $86(1 \%)$ patients receiving cefotaxime (93). Although the difference was not statistically significant, continued monitoring for seizure potential in future trials is recommended.

Imipenem versus meropenem: No direct comparative, prospective, randomized trials have been published comparing imipenem with meropenem.

\section{FEBRILE NEUTROPENIA}

Imipenem: Imipenem has been extensively studied in the management of febrile neutropenia (94-99). In the largest prospective, randomized, single-blind study, Leyland et al (100) treated 252 febrile episodes with either imipenem or a combination of piperacillin and gentamicin (Table 7). Success, defined as a temperature less than $37.5^{\circ} \mathrm{C}$ by $72 \mathrm{~h}$ and maintained for $48 \mathrm{~h}$, was achieved by $59 \%$ of patients in the imipenem group and by $56 \%$ of the piperacillin/gentamicin group (100). Patients requiring additional antimicrobials or antifungal agents to manage fever were considered treatment failures. In contrast, Cornelissen et al (101) reported an imipenem success rate of $91 \%$ in 94 febrile neutropenic episodes. Only $18 \%$ of episodes were considered fever of unknown origin, with $82 \%$ classified as acquired infections. Ciprofloxacin (500 mg bid) was used prophylactically in $65 \%$ of febrile episodes, in patients with hematological malignancy expected to be profoundly neutropenic for more than one week. Seventy-six per cent of causative microorganisms were Gram-positive. The most pronounced difference in efficacy was reported for microbiologically documented infections caused primarily by Gram-positive organisms (imipenem 89\% versus gentamicin plus cefuroxime or cephalothin $53 \%, \mathrm{P}=0.025$ ) (101). Another trial reported success rates, defined as complete disappearance 
of all clinical and laboratory evidence of infection, in $77 \%$ of 100 evaluable febrile episodes treated with imipenem $(500 \mathrm{mg}$ every 6 h) (Table 7) (102).

Meropenem: Few studies are available investigating meropenem for the management of febrile neutropenic patients. A recent study of 304 evaluable episodes of febrile neutropenia compared ceftazidime ( $2 \mathrm{~g}$ tid) with meropenem (1 $\mathrm{g}$ tid) (103). Response rates, defined as resolution of all signs and symptoms without modification of the empirical regimen, were $41 \%$ and $44 \%$, respectively, and were not statistically or clinically different ( $95 \% \mathrm{Cl} 0.71$ to 1.76 ) (103).

Imipenem versus meropenem: No direct comparative, prospective, randomized trials have been published comparing imipenem with meropenem.

\section{SUMMARY OF CLINICAL TRIALS}

The majority of prospective, randomized trials published in peer reviewed journals had an open design and used meropenem in doses of $1 \mathrm{~g}$ every $8 \mathrm{~h}$ or imipenem at $500 \mathrm{mg}$ every $6 \mathrm{~h}$ or $1 \mathrm{~g}$ every $8 \mathrm{~h}$. In direct comparisons of imipenem and meropenem with identical dosing regimens, there does not appear to be a clinically or statistically significant difference for treatment of intra-abdominal infections or acute bacterial exacerbations of chronic obstructive pulmonary disease. Direct comparisons were not available for other severe life-threatening infections including septicemia, bacterial meningitis and febrile neutropenia.

There appears to be no clinically significant difference in the treatment of serious, life-threatening infections with imipenem or meropenem compared with standard antimicrobial regimens. Although only four trials provide a direct comparison of imipenem with meropenem, clinical cure rates from several trials against standard comparators suggest that imipenem and meropenem have similar efficacy for the treatment of serious life-threatening infections. Imipenem dose regimens of $500 \mathrm{mg}$ every $6 \mathrm{~h}(73,75,84,87,101,102)$ and $1 \mathrm{~g}$ every $8 \mathrm{~h}(74,84,100)$ and meropenem $1 \mathrm{~g}$ every $8 \mathrm{~h}$ $(65,66,76-79,88,103)$ have been reported to be effective in the treatment of serious infections. One exception involves using imipenem for the treatment of bacterial meningitis because imipenem can cause seizures. In this case, meropenem should be considered the preferred carbapenem.

\section{ADVERSE EFFECTS}

Mild, self-limiting adverse effects reported with meropenem are similar to those reported with imipenem $(1,4,5,104$, 105). The most common adverse effects reported with meropenem and imipenem include local irritation at the injection site, diarrhea, rash, nausea, vomiting and pruritus (105). All of these adverse effects reversed upon discontinuation of the antibiotic, and none were reported to exceed incidences associated with other beta-lactams. Adverse events requiring drug withdrawal occurred in $1.4 \%$ of patients treated with meropenem and $1.8 \%$ of patients treated with imipenem (105).

Both imipenem and meropenem can affect laboratory tests. Like other beta-lactams, imipenem and meropenem can cause mild, transient increases in hepatic enzymes such as alanine aminotransferase, aspartate aminotransferase, alkaline phosphatase and lactate dehydrogenase (less than $5 \%)(104,105)$. In addition, meropenem and imipenem have been reported to cause increases in serum creatinine and serum urea (less than $1 \%$ ). The most frequent drug-induced hematological changes are thrombocytosis and eosinophilia (less than $2 \%$ ). No significant differences in the frequency of these altered laboratory tests have been reported between meropenem and imipenem $(104,105)$. Both meropenem and imipenem display cross-allergenicity with other beta-lactam antibiotics and, thus, are contraindicated in patients with a history of anaphylactic reactions to penicillins and cephalosporins.

A notable adverse effect associated with imipenem is the development of seizures. Phase 3 trials and postmarketing surveillance have documented the incidence of imipenem induced seizures to be $1.5 \%$ to $2.0 \%(105,106)$. Risk factors for seizures include impaired renal function, pre-existing central nervous system disease or infection, stroke or past history of seizures $(105,106)$. As mentioned previously, in one small clinical trial of meningitis, imipenem was associated with a $33 \%$ incidence of seizures (91). In contrast, both animal data and noncomparative clinical trials demonstrate that meropenem has a lower propensity than imipenem to cause seizures $(105,107)$. As a result of these data, meropenem is indicated for the treatment of meningitis, while imipenem is not (108).

\section{SUMMARY AND PHARMACOECONOMIC CONSIDERATIONS}

Meropenem and imipenem are clearly, equally efficacious (bacteriologically and clinically) for the treatment of serious infections. This is not surprising because they display similar in vitro activity and pharmacokinetics. Meropenem, however, offers the advantages of use for the treatment of meningitis because it has a lower likelihood of causing seizures than imipenem. In addition, meropenem's recommended dose regimen for the treatment of serious infections ( $1 \mathrm{~g}$ every $8 \mathrm{~h}$ ) (108) requires one fewer dose per day than imipenem's regimen $(500 \mathrm{mg}$ every $6 \mathrm{~h}$ ) (109). This translates into cost savings (approximately $\$ 5.00 /$ day) in nursing and pharmacy preparation time and in materials (110). We believe that there is no clinical relevance of the increased stability of meropenem to dehydropeptidase 1 and consequently no need to administer cilastatin concurrently, which is required with each dose of imipenem. Acquisition cost comparison between meropenem ( $1 \mathrm{~g}$ every $8 \mathrm{~h}$ or $3 \mathrm{~g} /$ day) and imipenem (500 mg every $6 \mathrm{~h}$ or $2 \mathrm{~g} /$ day) for the treatment of serious infections (in patients with normal renal function) suggests that meropenem is significantly more expensive (approximately $\$ 142 /$ day) than imipenem (approximately \$98/day) (108-110). However, the higher acquisition cost for meropenem is slightly offset by the approximate saving of $\$ 5.00 /$ day and convenience with meropenem as a result of fewer administered doses per day (every $6 \mathrm{~h}$ for imipenem versus every $8 \mathrm{~h}$ for meropenem).

Present studies support the use of meropenem $500 \mathrm{mg}$ every $8 \mathrm{~h}$ only for the treatment of mild to moderate infections 
(urinary tract, skin and soft tissue, low risk intra-abdominal infections and community acquired pneumonia requiring hospitalization) (67,111-113). Whether meropenem $500 \mathrm{mg}$ every $8 \mathrm{~h}$ can be used for the treatment of serious infections is not known because no clinical data are available for evaluation.

ACKNOWLEDGEMENTS: The meeting of the Canadian Carbapenem Discussion Group was supported by Merck Frosst. Members of the discussion group were chosen by Drs George Zhanel and Andy Simor. Advisory committee members were chosen to present unbiased expert opinion (MD or PharmD) on carbapenems and to reflect all regions of Canada. Members of the Canadian Carbapenem Discussion Group were George Zhanel, University of Manitoba, Winnipeg, Manitoba; Andrew Simor, Sunnybrook Health Sciences Centre, Toronto, Ontario; Lavern Vercaigne, University of Manitoba, Winnipeg, Manitoba; Lionell Mandell, McMaster University, Hamilton, Ontario; Kathryn Slayter, Queen Elizabeth II Health Sciences Centre, Halifax, Nova Scotia; Murray Ducharme, Université de Montréal, Montréal, Québec; Noel Lampron, Hôpital Laval, Ste-Foy, Quebec; Tom Chin, St Michael's Hospital, Toronto, Ontario; Sandra Tailor, Sunnybrook Health Sciences Centre, Toronto, Ontario; Gary Garber, Ottawa General Hospital, Ottawa, Ontario; Alfred Gin, Health Sciences Centre, Winnipeg, Manitoba; Godfrey Harding, St Boniface General Hospital, Winnipeg, Manitoba; Robert Ariano, St Boniface General Hospital, Winnipeg, Manitoba; Kurt Williams, Royal University Hospital, Saskatoon, Saskatchewan; Erwin Friesen, Capital House Authority, Edmonton, Alberta; Tom Louie, University of Calgary, Calgary, Alberta; Steve Shalansky, Lions Gate Hospital, Vancouver, British Columbia; and Marie Gribble, University of British Columbia, Vancouver, British Columbia.

The authors thank M Wegrzyn for expert secretarial assistance. Dr Robert Ariano provided comparative carbapenem pharmacokinetic simulations and their interpretation.

\section{REFERENCES}

1. Barza M. Imipenem: First of a new class of beta-lactam antibiotics. Ann Intern Med 1985;103:552-60.

2. Kahan FM, Kropp H, Sundellof JG, et al. Thienamycin: Development of imipenem-cilastatin. J Antimicrob Chemother 1983;12:1-35.

3. Neu HC, Labthavikul P. Comparative in vitro activity of $\mathrm{N}$-formimidoyl thienamycin against Gram-positive and Gram-negative aerobic and anaerobic species and its $\beta$-lactamase stability. Antimicrob Agents Chemother 1982;21:180-7.

4. Tally FP, Jacobus NV, Gorbach SL. In vitro activity of $\mathrm{N}$-formimidoyl thienamycin (MK0787). Antimicrob Agents Chemother 1980;18:642-4.

5. Pryka RD, Haig GM. Meropenem: A new carbapenem antimicrobial. Ann Pharmacother 1994;28:1045-54.

6. Wiseman LR, Wagstaff AJ, Brogden RN, et al. Meropenem. A review of its antibacterial activity, pharmacokinetic properties and clinical efficacy. Drugs 1995;50:73-101.

7. Edwards. Meropenem: a microbiological overview. J Antimicrob Chemother 1995;36(Suppl A):1-17.

8. Clissold SP, Todd PA, Campoli-Richards M. Imipenem/cilastatin: A review of its antibacterial activity, pharmacokinetic properties and therapeutic efficacy. Drugs 1987;33:183-241.

9. Yourassowsky E, Vander Linden MP, Crokaert F. Antibacterial effect of meropenem and imipenem on Proteus mirabilis. J Antimicrob Chemother 1990;26:185-92.

10. Ferrara A, Grassi G, Grassi FA, et al. Bactericidal activity of meropenem and interactions with other antibiotics. J Antimicrob Chemother 1989;24(Suppl A):239-50.

11. Kitzis MD, Acar JF, Gutmann L. Antibacterial activity of meropenem against Gram-negative bacteria with a permeability defect against staphylococci. J Antimicrob Chemother 1989;24(Suppl A):125-32.
12. Sumita Y, Fukasawa M, Okuda T. Affinities of SM 7338 for penicillin-binding proteins and its release from these proteins in Staphylococcus aureus. Antimicrob Agents Chemother 1990;34:484-6.

13. Sumita Y, Fukasawa M, Okuda T. Comparison of two carbapenems, SM 7338 and imipenem: affinities for penicillin binding proteins and morphological changes. J Antibiotic 1990;43:314-20.

14. Sanders CC, Sanders WE, Thompson KS, et al. Meropenem: activity against resistant Gram-negative bacteria and interactions with $\beta$-lactamases. J Antimicrob Chemother 1989;24(Suppl A):187-96.

15. Yang Y, Livermore DM. Interactions of meropenem with class 1 chromosomal $\beta$-lactamases. J Antimicrobial Chemother 1989;24(Suppl A):207-17.

16. Jones RN, Barry AL, Thornsberry C. In vitro studies of meropenem. J Antimicrob Chemother 1989;24(Suppl A):9-29.

17. Kitzis MD, Liassine N, Ferré B, et al. In vitro activities of 15 oral $\beta$-lactams against Klebsiella pneumoniae harbouring new extended spectrum beta-lactamases. Antimicrob Agents Chemother 1990;34:1783-6.

18. Chanal C, Sirot M, Chanal M, et al. Comparative in vitro activity of meropenem against clinical isolates including Enterobacteriaceae with expanded-spectrum beta-lactamases. J Antimicrob Chemother 1989;24(Suppl A):133-41.

19. Labia R, Morand A, Tiwari K, et al. Interactions of meropenem with beta-lactamases, including enzymes with extended spectrum activity against third-generation cephalosporins. J Antimicrob Chemother 1989;24(Suppl A):219-23.

20. Livermore DM. Carbapenemases. J Antimicrob Chemother 1992;29:609-13.

21. Rasmussen BA, Bush K. Carbapenem-hydrolyzing $\beta$-lactamases. Antimicrob Agents Chemother 1997;41:223-32.

22. Zhanel GG, Hoban DJ, Harding GKM. Postantibiotic effect: A review of in vitro and in vivo data. Ann Pharmacother 1991;25:478-84.

23. Zhanel GG, Craig WA. Pharmacokinetic contributions to postantibiotic effects: Focus on aminoglycosides. Clin Pharmacokinet 1994;27:377-92.

24. Hanberger H, Svensson E, Nilsson LE, Nilsson M. Pharmacodynamic effects of meropenem on Gram-negative bacteria. Eur J Clin Microbiol Infect Dis 1995;14:383-90.

25. Nordmann P, Mariotte S, Naas T, et al. Biochemical properties of a carbapenem-hydrolyzing $\beta$-lactamase from Enterobacter cloacae and cloning of the gene into Escherichia coli. Antimicrob Agents Chemother 1993;37:936-46.

26. Livermore DM. Interplay of impermeability and chromosomal beta-lactamase in carbapenem resistance in clinical isolates of Pseudomonas aeruginosa. J Antimicrob Chemother 1991;28:199-207.

27. Margaret BS, Drusano GL, Standiford HC. Emergence of resistance to carbapenem antibiotics in Pseudomonas aeruginosa. J Antimicrob Chemother 1989;24(Suppl A):161-7.

28. Livermore DM. Mechanisms of resistance to $\beta$-lactam antibiotics. Scand J Infect Dis 1991;78(Suppl):7-16.

29. Satake S, Yoshihara E, Nakae T. Diffusion of $\beta$-lactam antibiotics through liposome membranes reconstituted from purified porins of the outer membranes of Pseudomonas aeruginosa. Antimicrob Agents Chemother 1990;34:685-90.

30. Kayser FH, Morenzoni G, Strassle A, Hadorn K. Activity of meropenem against Gram-positive bacteria. J Antimicrob Chemother 1989;24(Suppl A):101-12.

31. Neu HC, Novelli A, Chin NX. In vitro activity and beta-lactamase stability of a new carbapenem SM-7338. Antimicrob Agents Chemother 1989;33:1009-18.

32. Jones RN, Aldridge KE, Allen SD, et al. Multicentre in vitro evaluation of SM-7338, a new carbapenem. Antimicrob Agents Chemother 1989;33:562-5.

33. Bauerfeind A, Jungwirth R, Schweighart S. In vitro activity of meropenem, imipenem, and penem HRE664 and ceftazidime against clinical isolates from West Germany. J Antimicrob Chemother 1989;24(Suppl A):73-84.

34. Clarke AM, Zemcov SJV. In vitro activity of meropenem against clinical isolates obtained in Canada. J Antimicrob Chemother 1989;24(Suppl A):47-55.

35. Forward K, Franks P, Low D, et al. A cross Canada survey of 
resistance to piperacillin-tazobactam and other antibiotics against 2,747 aerobic blood cultures isolatees. Interscience Conference on Antimicrobial Agents and Chemotherapy. Toronto,September 28 to October 1, 1997. (Abst E14)

36. Jones R, Pfaller M, Fuchs P, et al. Piperacillin/tazobactam (YTR 830) combination: Comparative antimicrobial activity against 5889 recent aerobic clinical isolates and 60 Bacteroides fragilis group strains. Diagn Microbiol Infect Dis 1989;12:489-94.

37. Barveny I. In vitro activity of imipenem - a review. Eur J Clin Microbiol 1984;3:456-62.

38. Tally FP, Jacobus NV, Gorback SL. In vitro activity of $\mathrm{N}$-formimidoyl thienamycin (MK 0787). Antimicrob Agents Chemother 1980;18:642-4.

39. Jones RN. Review of the in vitro spectrum of activity of imipenem. Am J Med 1985;7(6A)8:22-32.

40. Hoban DJ, Jones RN, Yamane N, et al. In vitro activity of three carbapenem antibiotics: Comparative studies with biapenem (L-627) imipenem and meropenem against aerobic pathogens isolated worldwide. Diagn Microbiol Infect Dis 1993;17:299-305.

41. Jorgensen JH, Maher LA, Howell AW. Activity of a new carbapenem antibiotic, meropenem, against Haemophilus influenzae strains with $\beta$-lactamase and non-enzyme mediated resistance to ampicillin. Antimicrob Agents Chemother 1991;35:600-2.

42. Harabe E, Kawai Y, Kanazawa K. In vitro and in vivo antibacterial activities of meropenem, a new carbapenem antibiotic. Drugs Exp Clin Res 1992;18:37-46.

43. Sader HS, Jones RN. Antimicrobial activity of the new carbapenem biapenem compared to imipenem, meropenem and other broad spectrum beta lactam drugs. Eur J Clin Microbiol Infect Dis 1993;12:384-91.

44. Sumita $\mathrm{Y}$, Inoue $\mathrm{M}$, Mitsuhashi S. In vitro antibacterial activity and beta-lactamase stability of a new carbapenem SM-7338. Eur J Clin Microbiol 1989;8:908-16.

45. Ravizzola G, Pinsi G, Gonzales R, et al. Antibacterial activity of a new carbapenem meropenem (SM-7338) against clinical isolates. Eur J Clin Microbiol Infect Dis 1989;8:1053-61.

46. Lewis C, Doherty C, Gowan J. In vitro activities of meropenem PD 127391, PD 131628, ceftazidime chloramphenicol cotrimoxazole and ciprofloxacin against Pseudomonas cepacia. Antimicrob Agents Chemother 1993; Jan 37;123-5.

47. Linares J, Alonso T, Perez JL, et al. Decreased susceptibility of penicillin-resistant pneumococci to twenty-four beta-lactam antibiotics. J Antimicrob Chemother 1992;30:279-88.

48. Garcia-Rodriguez JA, Garcia-Sanchez JE, Trujillano I, Sanchez de San Lorenzo A. Meropenem: in vitro activity and kinetics of activity against organism of the Bacteroides fragilis group. J Antimicrob Chemother 1991;27:599-606.

49. Murray PR, Niles AC. In vitro activity of meropenem (SM-7338) imipenem and five other antibiotics against anaerobic clinical isolates. Diagn Microbiol Infect Dis 1990;13:57-61.

50. Nord CE, Lindmark A, Personn I. Susceptibility of anaerobic bacteria to meropenem. J Antimicrob Chemother 1989;24 (Suppl A):113-7.

51. Drusano GL, Hutchison M. The pharmacokinetics of meropenem. Scand J Infect Dis 1995;96(Suppl):11-6.

52. Nilsson-Ehle I, Hutchison M, Haworth SJ, Norrby SR. Pharmacokinetics of meropenem compared to imipenem-cilastatin in young healthy males. Eur J Clin Microbiol Infect Dis 1991;10:85-8.

53. Barza M. Imipenem: First of a new class of beta-lactam antibiotics. Ann Intern Med 1985;103:552-60.

54. Gibson TP, Demetriades JL, Bland JA. Imipenem/cilastatin: Pharmacokinetic profile in renal insufficiency. Am J Med 1985;78(Suppl 6A):54-61.

55. Lovering AM, Vickery CJ, Watkins DS, et al. The pharmacokinetics of meropenem in surgical patients with moderate or severe infections. J Antimicrob Chemother 1995;36:165-72.

56. Bedikian A, Okamoto MP, Nakahiro RK, et al. Pharmacokinetics of meropenem in patients with intra-abdominal infections. Antimicrob Agents Chemother 1994;38:151-4.

57. Dagan R, Velghe L, Rodda JL, Klugman KP. Penetration of meropenem into the cerebralspinal fluid of patients with inflamed meninges. J Antimicrob Chemother 1994;34:175-9.

58. Hextall A, Andrews JM, Donovan IA, Wise R. Intraperitoneal penetration of meropenem. J Antimicrob Chemother 1991;27:314-5.

59. Modai J, Vittecoq D, Decazes JM, Wolff M, Meulemans A. Imipenem penetration into cerebrospinal fluid of patients with bacterial meningitis. In: Program and abstracts of the twenty-fourth Interscience Conference on Antimicrobial Agents and Chemotherapy. Washington, DC: American Society for Microbiology; 1984:192. (Abst 601)

60. Chimata M, Mitsumasa N, Suzuki Y, Shimomura M, Kakuta S. Pharmacokinetics of meropenem in patients with various degress of renal function, including patients with end-stage renal disease. Antimicrob Agents Chemother 1993;37:229-33.

61. Chambers HF, Neu HC. Other $\beta$-lactam antibiotics. In: Mandell GL, Bennett JE, Dolin R, eds. Principles and Practice of Infectious Diseases. New York: Churchill Livingstone, 1995:264-72.

62. Bax RP, Bastain W, Featherstone A, et al. The pharmacokinetics of meropenem in volunteers. J Antimicrob Chemother 1989;24(Suppl A):311-20.

63. Norrby SR, Alestig K, Bjornegard B. Urinary recovery of $\mathrm{N}$-formimidoyl thienamycin (MK 0787) as affected by co-administration of $\mathrm{N}$-formimidoyl thienamycin dehydropeptidase inhibitors. Antimicrob Agents Chemother 1983;23:300-7.

64. Pryka RD, Haig GM. Meropenem: A new carbapenem antimicrobial. Ann Pharmacother 1994;28:1045-54.

65. Kanellakopoulou K, Giamarellou H, Papadothomakos P, et al. Meropenem versus imipenem in the treatment of intraabdominal infections requiring surgery. Eur J Clin Microbiol Infect Dis 1993;12:449-53.

66. Geroulanos SJ and the Meropenem Study Group. Meropenem versus imipenem/cilistatin in intra-abdominal infections requiring surgery. J Antimicrob Chemother 1995;36 (Suppl A):191-205.

67. Brismar B, Malmborg AS, Tunevall G, et al. Meropenem versus imipenem/cilastatin in the treatment of intra-abdominal infections. Antimicrob Chemother 1995;35:139-48.

68. Hamacher J, Vogel F, Lichey J, et al. Treatment of acute bacterial exacerbations of chronic obstructive pulmonary disease in hospitalised patients - a comparison of meropenem and imipenem/cilistatin. J Antimicrob Chemother 1995;36 (Suppl A):121-33.

69. Hulley SB, Cummings SR, eds. Designing Clinical Research. Baltimore: Williams and Wilkins, 1988:217.

70. Guerra JG, Casalino E, Palomino JC, et al. Imipenem/cilastatin versus gentamicin/clindamycin for the treatment of moderate to severe infections in hospitalized patients. Rev Infect Dis 1985; 7(Suppl 3):S463-70.

71. Uhari M, Seppanen J, Heikkinen E. Imipenem-cilastatin vs tobramycin and metronidazole for appendicitis-related infections. Pediatr Infect Dis J 1992;11:445-50.

72. Eklund AE, Nord CE and the Swedish Study Group. A randomized multicenter trial of piperacillin/tazobactam versus imipenem/cilastatin in the treatment of severe intra-abdominal infections. J Antimicrob Chemother 1993;31(Suppl A):79-85.

73. Poenaru D, De Santis M, Christou NV. Imipenem versus tobramycin-antianaerobe antibiotic therapy in intra-abdominal infections. Can J Surg 1990;33:415-22.

74. Niinikoski J, Havia T, Alhava E, et al. Piperacillin/tazobactam versus imipenem/cilastatin in the treatment of intra-abdominal infections. Surg Gynecol Obstet 1993;176:255-61.

75. Solomkin JS, Dellinger EP, Christou NV, Bustuttil RW. Results of a multicenter trial comparing imipenem/cilastatin to tobramycin/clindamycin for intra-abdominal infections. The Intra-Abdominal Infection Study Group. Ann Surg 1996;212:581-91.

76. Huizinga WKJ, Warren BL, Baker LW, et al. Antibiotic monotherapy with meropenem in the surgical management of intra-abdominal infections. J Antimicrob Chemother 1995;36(Suppl A):179-89.

77. Condon RE, Walker AP, Sirinek KR, et al. Meropenem versus tobramycin plus clindamycin for treatment of intraabdominal infections: results of a prospective, randomized, double-blind clinical trial. Clin Infect Dis 1995;21:544-50.

78. Berne TV, Yellin AE, Appleman MD, Heseltine PNR, Gill MA. Meropenem versus tobramycin with clindamycin in the 
antibiotic management of patients with advanced appendicitis. J Am Coll Surg 1996;182:403-7.

79. Wilson SE. Results of a randomized, multicenter trial of meropenem vs clindamycin/tobramycin for the treatment ofintra-abdominal infections. Clin Infect Dis 1997;24 (Suppl 2):S197-206.

80. Lode $\mathrm{H}$, Wiley E, Olschewski $\mathrm{P}$, et al. Prospective randomized clinical trials of new quinolones versus $\beta$-lactam antibiotics in lower respiratory tract infections. Scand J Infect Dis 1990;68(Suppl):50-5.

81. Hartenauer U, Weilmann LS, Bodmann KF, Ritzerfeld W, Asmus S, Koch EMW. Comparative clinical trail of ceftazidime and imipenem/cilastatin in patients with severe nosocomial pneumonias and septicaemias. J Hosp Infect 1990;15 (Suppl A):61-4

82. Krilov LR, Blumer JL, Stern RL, Hartstein AI, Iglewski BN, Goldmann DA. Imipenem/cilistatin in acute pulmonary exacerbations of cystic fibrosis. Rev Infect Dis 1985;7(Suppl 3):S482-9.

83. Siami GA, Wilkins WT, Christman JW. Comparison of ciprofloxacin with imipenem in the treatment of severe pneumonia in hospitalized geriatric patients. Drugs 1995;49(Suppl 2):436-8.

84. Fink MP, Snydman DR, Niederman MS, et al. Treatment of severe pneumonia in hospitalized patients: results of a multicenter, randomized, double-blind trial comparing intravenous ciprofloxacin with imipenem-cilastatin. Antimicrob Agents Chemother 1994;38:547-57.

85. Byrne S, Maddison J, Connor P, et al. Clinical evaluation of meropenem versus ceftazidime for the treatment of Pseudomonas spp. infections in cystic fibrosis patients. J Antimicrob Chemother 1995;36(Suppl A):135-43.

86. Linton DM, Aitchison JM, Potigieter PD. Evaluation of the efficacy and tolerance of intravenously administered imipenem/cilastatin in the treatment of septicemia. South Aust Med J 1989;75:529-31.

87. Norrby SR, Finch RG, Glauser M. Monotherapy in serious hospital-acquired infections: a clinical trial of ceftazidime versus imipenem/cilastatin. European Study Group. J Antimicrob Chemother 1993;31:927-37.

88. Solberg CO, Sjursen H. Safety and efficacy of meropenem in patients with septicaemia: a randomized comparison with ceftazidime, alone or combined with amikacin. J Antimicrob Chemother 1995;36(Suppl A): 157-66.

89. Spriet A, Simon P, eds. Methodology of Clinical Drug Trials Boston: Karger, 1985:171.

90. Eng RHK, Munsif AN, Yangco BG, Smith SM, Chmel H. Seizure propensity with imipenem. Arch Intern Med 1989;149:1881-3.

91. Wong VK, Wright HT, Ross LA, et al. Imipenem/cilastatin treatment of bacterial meningitis in children. Pediatr Infect Dis J 1991;10:122-5

92. Pestotnik SL, Classen DC, Evans RS, Stevens LE, Burke JP. Prospective surveillance of imipenem/cilastatin use and associated seizures using a hospital information system. Ann Pharmacother 1993;27:497-501.

93. Klugman KP, Dagan R. Randomized comparison of meropenem with cefotaxime for treatment of bacterial meningitis. Meropenem Meningitis Study Group. Antimicrob Agents Chemother 1995;39:1140-6.

94. Schmutzard E, Williams KJ, Vukmirovits G, et al. A randomized comparison of meropenem with cefotaxime or ceftriaxone for the treatment of bacterial meningitis in adults. J Antimicrob Chemother 1995;36(Suppl A):85-97.

95. Bucaneve G, Menichetti F, Minotti V, Pasticci MB, Tonato M, Del Favero A. Cetriaxone versus imipenem/cilastatin as empirical monotherapy for infections in cancer patients. Chemotherapy 1989;35(Suppl 2):10-5.

96. Rolston KVI, Berkey P, Bodey GP, et al. A comparison of imipenem to ceftazidime with or without amikacin as empiric therapy in febrile neutropenic patients. Arch Intern Med 1992; 152:283-91.

97. Riikonen P. Imipenem compared with ceftazidime plus vancomycin as initial therapy for fever in neutropenic children with cancer. Pediatr Infect Dis J 1991;10:918-23.

98. Bodey GP, Alvarez ME, Jones PG, Rolston KVI, Steelhammer L, Fainstein V. Imipenem-cilastatin as initial therapy for febrile cancer patients. Antimicrob Agents Chemother 1986;30:211-4.

99. Bohme A, Just-Nubling G, Bergmann L, Shah PM, Stille W, Hoelzer D. A randomized study of imipenem compared to cefotaxime plus piperacillin as initial therapy of infections in granulocytopenic patients. Infection 1995;23:349-55.

100. Leyland MJ, Bayston KF, Cohen J, et al. A comparative study of imipenem versus piperacillin plus gentamicin in the initial management of febrile neutropenic patients with haematological malignancies. J Antimicrob Chemother 1992;30:843-54.

101. Cornelissen JJ, deGraeff A, Verdonck LF, et al. Imipenem versus gentamicin combined with either cefuroxime or cephalothin as initial therapy for febrile neutropenic patients. Antimicrob Agents Chemother 1992;36:801-7.

102. Liang R, Yung R, Chiu E, et al. Ceftazidime versus imipenem-cilastatin as initial monotherapy for febrile neutropenic patients. Antimicrob Agents Chemother 1990;34:1336-41.

103. The Meropenem Study Group of Leuven, London, and Nijmegen. Equivalent efficacies of meropenem and ceftazidime as empirical monotherapy of febrile neutropenic patients. J Antimicrob Chemother 1995;36:185-200.

104. Schuler D. Safety and efficacy of meropenem in hospitalized children: randomized comparison with cefotaxime alone and combined with metronidazole or amikacin. Meropenem Pediatric Study Group. J Antimicrob Chemother 1995;36 (Suppl A):99-108.

105. Norrby SR, Newell PA, Faulkner KL, Lesky W. Safety profile of meropenem: international clinical experience based on the first 3125 patients treated with meropenem. J Antimicrob Chemother 1995;36(Suppl A):207-23.

106. Job ML, Dretler RH. Seizure activity with imipenem therapy: Incidence and risk factors. Ann Pharmacother 1990;24:467-9.

107. Patel JB, Giles RE. Meropenem: evidence of lack of proconvulsive tendency in mice. J Antimicrob Chemother 1989;23(Suppl A):307-9.

108. Meropenem Product Monograph. Mississauga: Zeneca Pharma, 1996.

109. Simor A. Update on antibiotic dosage: Carbapenem usage. Phys Perspective 1996;1:1-2.

110. Hanis M, Brown G. Economic impact of once daily vs conventional administration of gentamicin and tobramycin. Pharmacoeconomics 1996;5:495-503.

111. Nichols RL, Smith JW, Geckler RW, Wilson SE. Meropenem vs imipenem/cilastatin in the treatment of hospitalized patients with skin and soft tissue infections. South Med J 1995;88:397-404

112. Cox CE, Holloway WJ, Geckler RW. A multi-center comparative study of meropenem and imipenem/cilastatin in the treatment of complicated urinary tract infections in hospitalized patients. Clin Infect Dis 1995;21:86-92.

113. Romanelli G, Cravarezza P. Intramuscular meropenem in the treatment of bacterial infections of the urinary and respiratory tracts. Italian Intramuscular Meropenem Study Group. J Antimicrob Chemother 1995;36(Suppl A):109-19. 


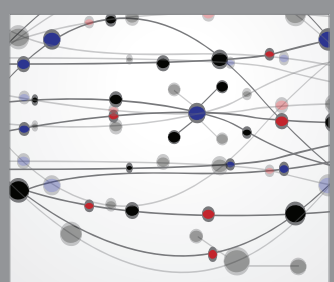

The Scientific World Journal
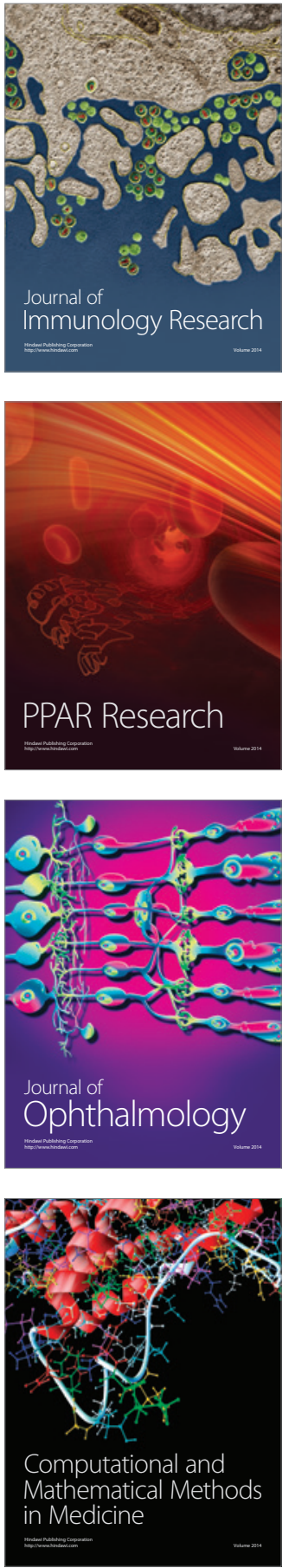

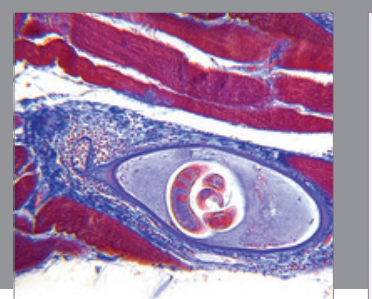

Gastroenterology Research and Practice

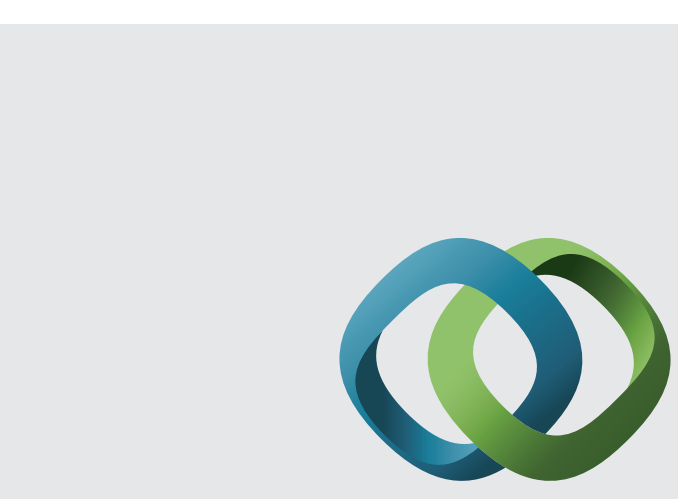

\section{Hindawi}

Submit your manuscripts at

http://www.hindawi.com
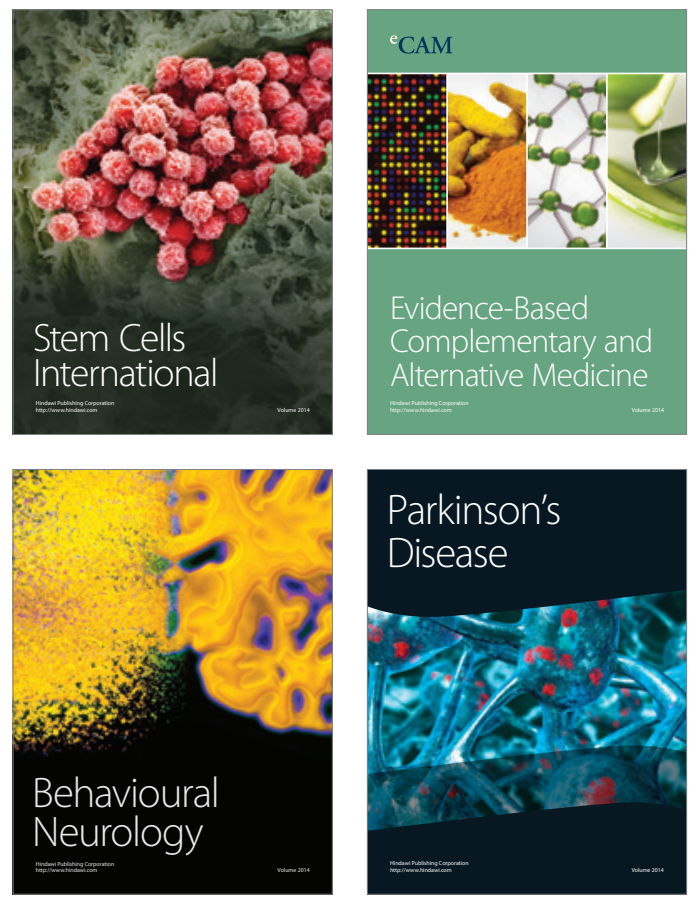
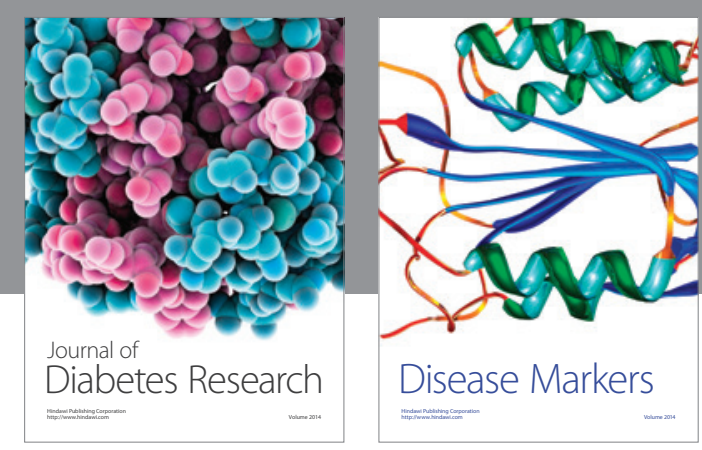

Disease Markers
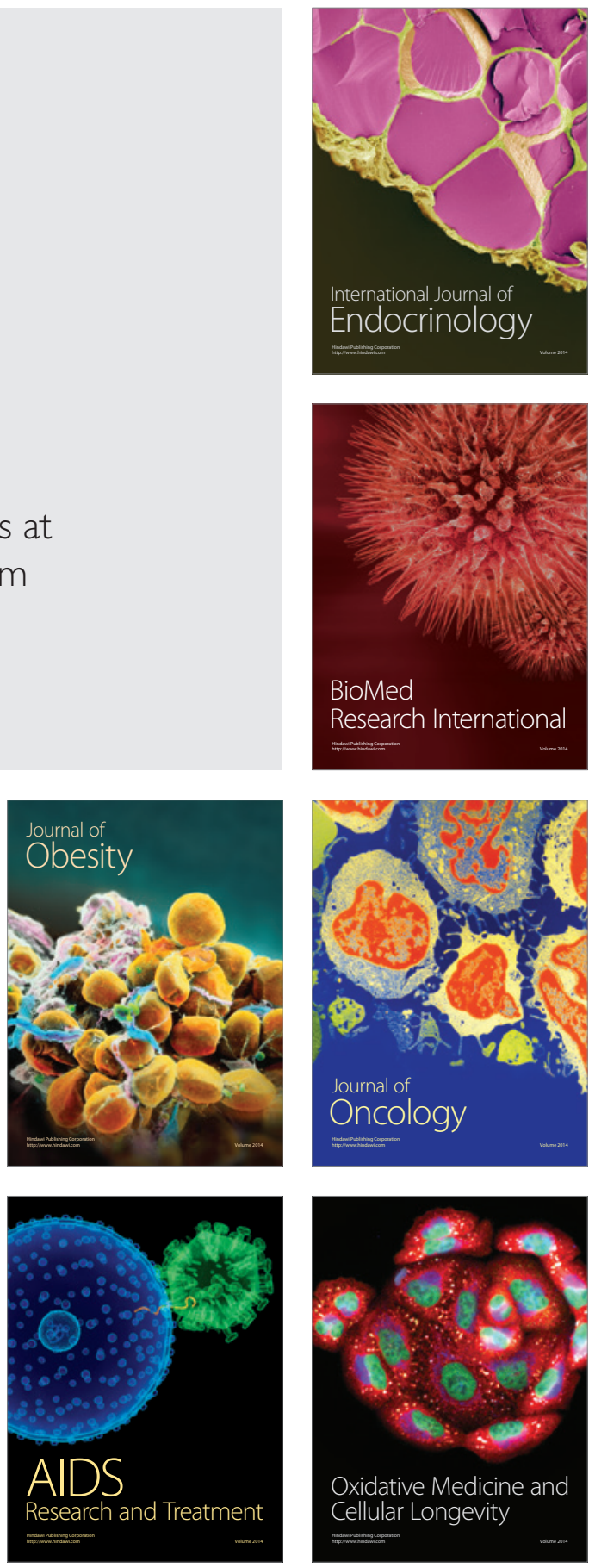